\begin{tabular}{|l|c|c|c|r|}
\hline $\begin{array}{l}\text { Cuadernos de Investigación Geográfica } \\
\text { Geographical Research Letters }\end{array}$ & 2018 & N $^{\circ} 44(2)$ & pp. 397-428 & $\begin{array}{r}\text { ISSN 0211-6820 } \\
\text { eISSN 1697-9540 }\end{array}$ \\
\hline
\end{tabular}

DOI: http://doi.org/10.18172/cig.3327

(C) Universidad de La Rioja

\title{
RUNOFF GENERATION IN MOUNTAIN CATCHMENTS: LONG-TERM HYDROLOGICAL MONITORING IN THE RIO VAUZ CATCHMENT, ITALY
}

\author{
G. ZUECCO ${ }^{1}$, D. PENNA ${ }^{2 *}$, M. BORGA ${ }^{1}$ \\ ${ }^{1}$ Department of Land, Environment, Agriculture and Forestry, University of Padua, Italy. \\ ${ }^{2}$ Department of Agricultural, Food and Forestry Systems, University of Florence, Italy.
}

\begin{abstract}
Trying to obtain a more detailed understanding of the hydrological functioning of mountain catchments represents an important challenge in the effort of counteracting possible consequences of climate and land use change on water resources availability. Long-term (>10 years) hydro-meteorological monitoring in small (typically $<10 \mathrm{~km}^{2}$ ) experimental catchments constitutes a valuable tool to achieve this goal. One of these sites is the Rio Vauz Catchment $\left(1.9 \mathrm{~km}^{2}\right)$, in the Italian Dolomites, that represents an excellent example of long-term snowmeltdominated catchment in Dolomitic regions. The strong elevation gradient of the Rio Vauz Catchment and the different physiographic properties of its nested subcatchments make this a unique site for investigating fundamental runoff generation mechanisms in mountain headwaters. In this work, we provide a review of physical processes that have been inferred from 12 years of hydrological monitoring in this catchment. We present the available dataset and summarize the main hydrological mechanisms that explain the internal functioning of the Rio Vauz Catchment, primarily focusing on three characterizing hydrological behaviours, namely thresholds, hysteresis and connectivity. The main control on surface and subsurface runoff threshold response is constituted by a combination of soil moisture antecedent conditions, rainfall amount and topography. Changes in hysteresis patterns (clockwise and anti-clockwise loops) between streamflow and soil moisture, water table depth and electrical conductivity were governed by distinct runoff generation processes and rainfall event characteristics. Hillsloperiparian-stream subsurface connectivity was controlled mainly by rainfall amount. The composition in environmental tracers (stable isotopes of water and electrical conductivity) in different water sources and the application of tracer-based mixing models helped to distinguish the geographical sources to runoff and to quantify the role of rainfall and snowmelt in streamflow. Finally, we define a perceptual model of runoff generation processes for dry and wet conditions that can be considered representative for many mountain headwater catchments in the world.
\end{abstract}


Generación de escorrentía en cuencas de montaña: Monitoreo hidrológico a largo plazo en la cuenca del Río Vauz, Italia

RESUMEN. Adquirir un conocimiento detallado sobre el funcionamiento hidrológico de cuencas de montaña representa un importante reto en el esfuerzo para paliar las posibles consecuencias del cambio climático y de los cambios de uso del suelo en la disponibilidad de los recursos hídricos. Las observaciones hidro-meteorológicas a largo plazo (>10 años) en pequeñas $\left(<10 \mathrm{~km}^{2}\right)$ cuencas experimentales constituye una herramienta muy valiosa para conseguir este objetivo. La cuenca del Río Vauz (1,9 $\mathrm{km}^{2}$ ) en los Dolomitas italianos, representa un excelente ejemplo de cuenca monitorizada a largo plazo, afectada por procesos de fusión de nieve en regiones dolomíticas. El fuerte gradiente altitudinal de la cuenca del Río Vauz y las diferentes propiedades fisiográficas de sus cuencas anidadas hace que éste sea un sitio único para investigar los mecanismos fundamentales de generación de escorrentía en cuencas de cabecera en zonas de montaña. En este trabajo se ofrece una revisión de los procesos físicos que se infieren a partir del seguimiento hidrológico que se ha llevado a cabo en esta cuenca a lo largo de 12 años. Se presenta la base de datos disponible y se sintetizan los procesos hidrológicos principales que explican el funcionamiento interno de la cuenca del Río Vauz, centrándose en los siguientes comportamientos hidrológicos: umbrales, histéresis y conectividad. El principal mecanismo que controla el umbral de respuesta de las escorrentías superficial y subsuperficial está constituido por la combinación de tres factores: condiciones antecedentes de la humedad del suelo, volumen de precipitación y topografía. Los cambios en los patrones de las curvas de histéresis (horarias y anti-horarias) entre caudal, humedad del suelo, nivel freático y conductividad eléctrica están determinados por la ocurrencia de procesos de generación de escorrentía diferentes y las características del evento de precipitación. La conectividad ladera-ribera-cauce está fundamentalmente controlada por el volumen de precipitación. La composición de los trazadores ambientales (isótopos estables del agua y conductividad eléctrica) en distintas fuentes de agua y la aplicación de modelos mixtos basados en trazadores ayudan a diferenciar las fuentes de escorrentía y cuantificar el papel de la lluvia y la fusión de nieve en el caudal. Finalmente, se define un modelo perceptual de procesos de generación de escorrentía en condiciones secas y húmedas que puede ser considerado representativo de muchas cuencas de cabecera en zonas de montaña del mundo.

Key words: mountain headwater catchment, long-term monitoring, runoff generation processes, tracers, hydrological functioning.

Palabras clave: cuenca de cabecera en zonas de montaña, monitorización a largo plazo, procesos de generación de escorrentía, trazadores, funcionamiento hidrológico.

Received: 22 May 2017

Accepted: 10 August 2017

* Corresponding author: Prof. Dr. Daniele Penna, Department of Agricultural, Food and Forestry Systems, University of Florence, via San Bonaventura 13, 50145, FlorenceFirenze, Italy. E-mail address: daniele.penna@unifi.it 


\section{Introduction}

Small mountain catchments, especially in the headwater zones of large and populated basins, are important sources of fresh water necessary for human life. Moreover, mountain catchments comprise the source areas and transient sinks for water, nutrients, sediments and biota that play an important role for the ecology of downstream areas (Sidle et al., 2000). Providing a quantitative characterization of runoff processes in mountain catchments is essential for assessing threats to critical habitats, designing civil infrastructure, reducing the spread of contaminants, evaluating best management practices, soil conservation and other environmental problems (Mirus and Loague, 2013). At the same time, increasing our knowledge of the hydrological functioning of these areas and, particularly, gaining detailed understanding of the processes that control streamflow generation may help to anticipate the hydrological consequences of climate change, land cover change and anthropogenic perturbations, supporting strategies to counteract these changes (Gallart et al., 2002; Frisbee et al., 2012).

Catchments, as environmental systems, are characteristically complex and heterogeneous (Kirchner, 2016), involving a range of physical processes (natural or anthropogenic) that may operate simultaneously and have different spatial and temporal influences (Zabaleta and Antigüedad, 2013). This is particularly evident for mountain headwater catchments where interactions between geology, geomorphology, vegetation and harsh topography, coupled with climatic forcing (sometimes distinctly different along elevation gradients) and multiple water inputs beyond rainfall (e.g., meltwater from snowpack, glaciers and permafrost, subsurface water from springs, talus and tile) make the hydrological response highly complex to decipher. Moreover, despite the availability of remotely-controlled sensors and the plethora of hydrological models, field work is still essential (Vidon, 2015). However, collecting good quality hydro-meteorological data in these conditions, and therefore understanding the hydrological behaviour of mountain catchments, remains challenging. In this context, small experimental catchments act as open laboratories that are useful for collection of high-quality measurements and, in turn, to investigate the complexities of combined physical, chemical and biological processes (Holko et al., 2015). Particularly, as stressed by the Braunschweig declaration (Schumann et al., 2010), small experimental catchments encompassing long-term observations ( $>10$ years) are very effective in coping with the issues of inter-annual variability of meteorological forcing and non-stationarity in hydrological processes.

In the last five decades, significant efforts have been made in different parts of the world to equip and maintain long-term experimental catchments in mountain settings. Among the oldest and most important long-term and rainfall-dominated catchments are the H.J. Andrews Experimental Forest, western Cascades Mountains, Oregon, USA (established in 1948); two uplands catchments in Plynlimon, Wales, UK (1968); the Maimai catchment in New Zealand, South Island (1974); the Rietholzbach catchment, Switzerland (1975); the Panola Mountain Research Watershed, Georgia, USA (1985); the Vallcebre (1989), Arnás (1996) and San Salvador catchments (1998), Spain; the Bruntland Burn, Scotland (2000); and the Weierbach catchment, Luxembourg (2002). Experimental and modelling studies in these sites have significantly advanced our comprehension of 
the hydrological functioning of mountain catchments. Long-term experimental sites have also been established in snowmelt-dominated mountain environments, where snow is an important component of the annual water budget and snowmelt plays a key role in generating streamflow. The Krycklan catchment $\left(67.8 \mathrm{~km}^{2}\right)$ with its subcatchments, in northern Sweden, which comprises a mosaic of wetland, lakes and forest, is likely the oldest long-term snowmelt-dominated experimental catchment. It was established in 1920 with the aim to integrate research in water quality, hydrology and aquatic ecology in the boreal region. More intensive efforts have been made in Krycklan in the last 30 years, and a presentation of available precipitation data is reported by Laudon et al. (2016). Very recent studies include the analysis of transit times (Amelia et al., 2016; Peralta-Tapia et al., 2016), streamflow variability (Karlsen et al., 2016; Teutschbein et al., 2016), hydrological thresholds and connectivity (Ali et al., 2015; Peralta-Tapia et al., 2015a, b), and water partitioning between vegetation and the other components of the water cycle (Tetzlaff et al., 2015). Another important site for hydrological processes understanding in snowmelt-dominated environments is the Hubbard Brook Experimental Forest, in the White Mountain National Forest (New Hampshire, USA). The site includes 10 catchments ranging in size between 0.12 and $0.77 \mathrm{~km}^{2}$, established between 1956 and 1995. Recent work at Hubbard Brook focused on stream solute dynamics (Gannon et al., 2015; Benettin et al., 2015), groundwater dynamics (Bailey et al., 2014; Gannon et al., 2014) and subcanopy precipitation recycling (Green et al., 2015). The Sleepers River Research Watershed is a mainly forested catchment $\left(111 \mathrm{~km}^{2}\right)$ in Vermont (USA). Investigations were initiated in 1959 to study water, energy and biogeochemical budgets over a range of scales, with a particular focus on water quality and tracer hydrology issues. A comprehensive review on the insight into streamflow generation processes obtained at the Sleepers is reported in Shanley et al. (2015) and references therein. Since 1961, research was conducted in the Tenderfoot Creek Experimental Forest (Montana, USA) to assess forest productivity, biodiversity and health as well as hydrological processes including hydrological connectivity and landscape control on runoff (Grabs et al., 2010; Jencso et al., 2010; Pacific et al., 2011), water quality (Pacific et al., 2010), and ecohydrology (Emanuel et al., 2010; Riveros-Iregui et al., 2011; Kaiser et al., 2013). A comprehensive collection of publications emerged from studies conducted at the Tenderfoot Creek Experimental Forest is reported in Abrahamson (2014). The Marmot Creek research basin $\left(10 \mathrm{~km}^{2}\right)$, located in the Rocky Mountain Front Ranges (Alberta, Canada) was established in 1962 to study the hydrological effects of forest management. The Marmot Creek catchment is currently instrumented with several permanent meteorological stations at different elevations, groundwater wells and stream gauges. Research focuses on mountain snow processes (snow accumulation and snowmelt), hydro-climatic trends and hydrological modelling (Pomeroy et al., 2012; Fang et al., 2013). Research projects in the Wolf Creek catchment (Yukon, Canada) were initiated in 1992 and include studies on water balance, hillslope runoff processes and runoff generation in permafrost areas by means of environmental tracers (Carey and Woo, 2001; Carey and Quinton, 2005). Hydrological measurements in the Alptal valley (Switzerland) started in 1965 with runoff monitoring in 11 stations. Nowadays, research in Alptal spans from snow hydrology and sediment transport to water quality, runoff generation processes and groundwater dynamics (Rinderer et al., 2014; Fischer et al., 
2015). The Uhlîrská catchment $\left(1.78 \mathrm{~km}^{2}\right)$, situated in the humid temperate mountainous region of the Jizera Mountains (northern Czech Republic) has been instrumented since 1982, and in the last ten years flow measurements have been coupled with the application of environmental tracers. Research in the Uhlirrská catchment mainly focused on processes driving subsurface runoff, preferential flow and streamflow generation (Šanda et al., 2009; Vogel et al., 2010; Šanda et al., 2014; Votrubova et al., 2017). Another longterm mountain site in central Europe is the Jalovecky Creek catchment $\left(22.2 \mathrm{~km}^{2}\right)$, in the Western Tatra Mountains (northern Slovakia). Hydrological research in the catchment started in 1986 and a particular attention was given to snow hydrological issues and runoff generation during snowmelt periods (Holko and Kostka, 2006, 2010; Holko et al., 2011).

Although there are several experimental catchments in snow-dominated areas, we found that very few of them are also characterized by high altitude gradients (e.g., Alptal, Val Ferret, see Simoni et al., 2011). Furthermore, despite the number of long-term instrumented sites in mountain catchments, until the beginning of the new millennium, to the best of our knowledge, there were no experimental sites in snowmelt-dominated Dolomitic environments. Dolomitic catchments have a very distinct landscape, with vertical rock cliffs and soil-mantled hillslopes originated from glacial or colluvial deposits, which can hide a complex subsurface aquifer due to the specific characteristics of the dolomitic rocks (Bosellini et al., 2003; Doglioni and Carminati, 2008). To improve the understanding of the hydrological functioning of such a complex system, in 2005 a new experimental catchment, the Rio Vauz Catchment (RVC, $1.9 \mathrm{~km}^{2}$ ) was created in the Dolomites, eastern Alps, northern Italy, by the hydrology group of the Department of Land, Environment, Agriculture and Forestry of the University of Padua. The location was chosen in a site considered representative for the geology, topography, soil characteristics and vegetation cover of the Dolomitic region. Since then, research conducted in the RVC helped to shed new light on runoff generation processes in steep mountain headwaters. The general aim of this paper is to revisit and summarize the main findings obtained in the last 12 years of hydro-meteorological monitoring in the RVC and its subcatchments, with the specific objective of providing a paradigm of hydrological functioning of Dolomitic mountain headwater catchments.

The paper is structured as follows: we firstly report a short description of the study area and then we provide a presentation of the instrumentation and of the available dataset. Then, we introduce an overview on the tracer signature of different water compartments, we revise three main hydrological behaviours occurring in the catchment (thresholds, hysteresis, connectivity) underlining the hydrological mechanisms at their base, and we finally conclude providing an overall description of runoff generation processes in Dolomitic mountain catchments.

\section{Study area}

The RVC is located in the Italian Dolomites, ranging in elevations from $1847 \mathrm{~m}$ a.s.l. (at the outlet) to $3152 \mathrm{~m}$ a.s.l. (Piz Boè). Mean annual precipitation is $1220 \mathrm{~mm} \mathrm{yr}^{-1}(49 \%$ falls as snow) and average monthly temperatures have a minimum of $-5.7^{\circ} \mathrm{C}$ in January 
and a maximum of $14.1{ }^{\circ} \mathrm{C}$ in July. The high elevation and the location in the internal area of the Alps determine that streamflow is mainly sustained by snowmelt and summer storm events. Land cover consists of subvertical Dolomitic rock cliffs in the upper part of the catchment (Fig. 1), while grassland, sparse Norway spruces and European larches are typical of elevations lower than $2200 \mathrm{~m}$ a.s.l. The geological setting mainly consists of Triassic calcareous rocks with peaks of stratified and structurally deformed dolomite rocks (Bosellini et al., 2003; Doglioni and Carminati, 2008). The complex geomorphology of the area determines the presence of two main superposed carbonate aquifers (corresponding to "Dolomia Principale" and "Dolomia Cassiana" formations; Penna et al., 2017) and minor aquifers formed by scree slopes, alluvial and colluvial deposits.

Within RVC, four subcatchments (Fig. 1) were instrumented for hydrometeorological monitoring: two rocky subcatchments representative of the upper part, Channel A (ChA) and Channel B (ChB), and two subcathments in the mid-lower part covered by grassland and sparse trees, Bridge Creek Catchment (BCC) and Larch Creek Catchment (LCC). The rocky subcatchments lie on the "Dolomia Principale" formation (dolomite), BCC lies on both "Dolomia Cassiana" (dolomite) and "San Cassiano" (carbonate and terrigenous sandstones and claystones) formations and LCC lies on the lower part of "San Cassiano" formation. ChA, ChB and BCC have similar catchment areas, while LCC is much smaller $\left(0.03 \mathrm{~km}^{2}\right.$, Table 1$)$. The two rocky catchments are very steep and have $<1 \%$ soil cover (Penna et al., 2017). BCC and LCC are soil-mantled catchments (soil cover $>90 \%$ ) with steep hillslopes, a distinct riparian zone $(8.6 \%$ of the catchment area in BCC (Penna et al., 2016), 4.4\% of the catchment area in LCC (Camporese et al., 2014)) and saturated areas. In the lower part of RVC cambisols with mull are the prevailing soil types, while soil texture is dominated by clay (range of 45$73 \%$ in the soil profile) and has a small fraction of silt (16-28\%) and sand (3-25\%).

Table 1. Main characteristics of the study catchments. ChA, Channel A; ChB, Channel B; BCC, Bridge Creek Catchment; LCC, Larch Creek Catchment; RVC, Rio Vauz Catchment.

\begin{tabular}{|l|c|c|c|c|c|}
\hline & ChA & ChB & BCC & LCC & RVC \\
\hline Area $\left(\mathbf{k m}^{2}\right)$ & 0.10 & 0.10 & 0.14 & 0.03 & 1.9 \\
\hline $\begin{array}{l}\text { Elevation } \\
\text { range } \\
(\mathbf{m} \text { a.s.l.) }\end{array}$ & $2657-3131$ & $2647-3152$ & $1932-2515$ & $1974-2128$ & $1847-3152$ \\
\hline Mean slope $\left(^{\circ}\right)$ & 36.6 & 40.9 & 29.9 & 25.9 & 31.8 \\
\hline Lithology & "Dolomia Principale" & $\begin{array}{l}\text { Cassiana" } \\
\text { and "San } \\
\text { Cassiano" }\end{array}$ & "San Cassiano" & $\begin{array}{l}\text { complex (see } \\
\text { Penna } \text { et al., } \\
\text { 2017) }\end{array}$ \\
\hline $\begin{array}{l}\text { Main land } \\
\text { cover }\end{array}$ & rock & grassland & $\begin{array}{l}\text { grassland and } \\
\text { sparse trees }\end{array}$ & $\begin{array}{l}\text { rock, } \\
\text { grassland and } \\
\text { sparse trees }\end{array}$ \\
\hline
\end{tabular}




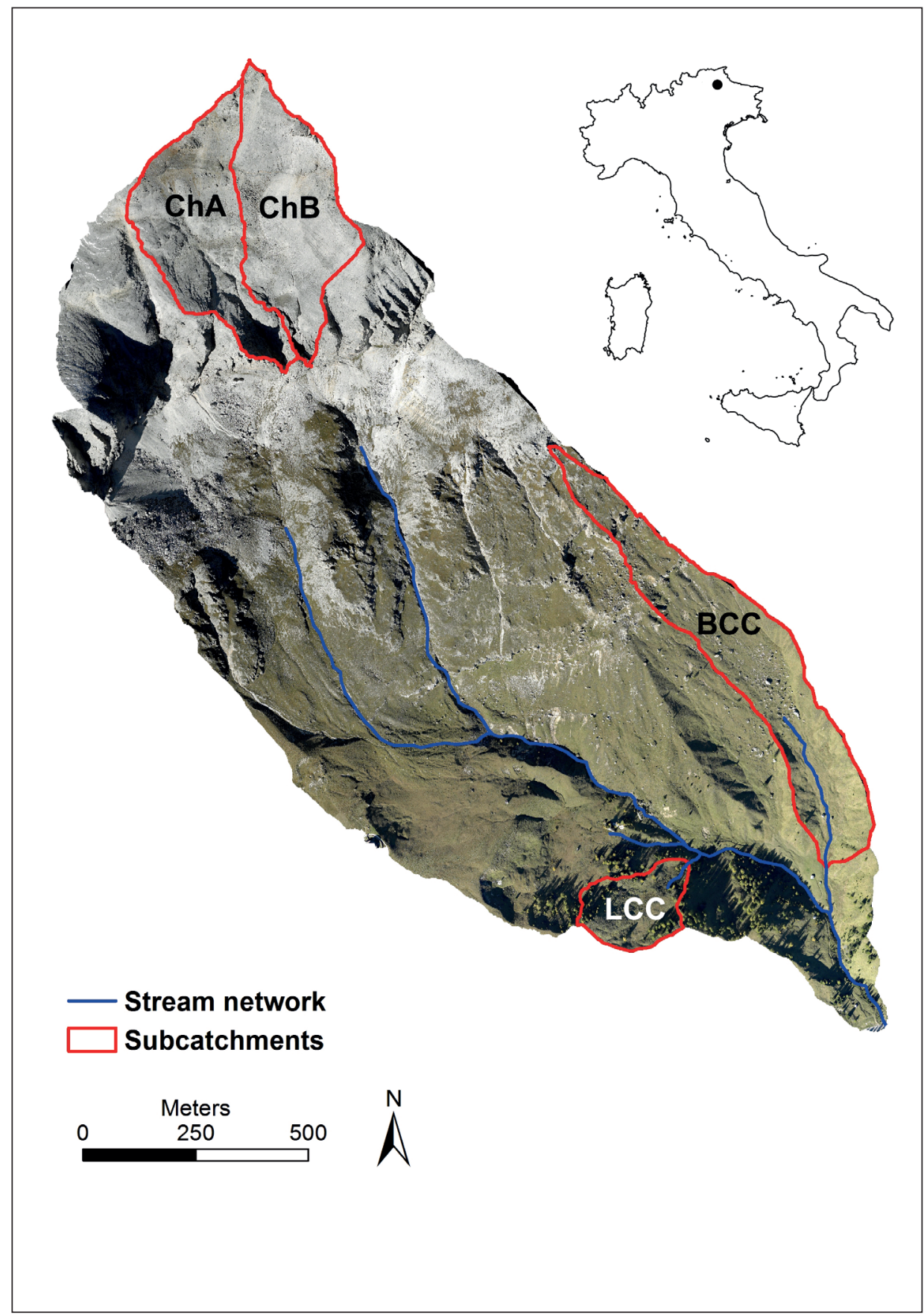

Figure 1. Map of Rio Vauz Catchment (RVC) and of the instrumented subcatchments, and position in Italy. ChA: Channel A; ChB: Channel B; BBC: Bridge Creek Catchment; LCC: Larch Creek Catchment. 


\section{Instrumentation and dataset}

\subsection{Data collection}

The hydro-meteorological monitoring of RVC has started in 2005 and is still ongoing in BCC (Fig. 2) and ChA (Table 2). Precipitation is measured by nonheated tipping buckets mainly from May to October at different locations with approximately one rain gauge installed per subcatchment in BCC, $\mathrm{ChB}$ and RVC. In addition, these data are compared and integrated with all year round measurements of precipitation (by heated rain gauges) and air temperature taken at two weather stations (about $2.5 \mathrm{~km}$ on the East and on the West of RVC) operated by the Agency for Environmental Protection of the Veneto Region (Penna et al., 2017). Water level is currently monitored by pressure transducers at $\mathrm{BCC}, \mathrm{RVC}$ and $\mathrm{ChA}$, while pressure transducers at the outlets of LCC and ChB were active until autumn 2013 and 2016, respectively. V-notch weirs are installed at the outlet of BCC and LCC. Water level was converted to streamflow only in BCC and LCC based on the weir equation and volumetric methods, respectively.

To understand the role of topography on the spatial and temporal variability of soil moisture, measurements of soil moisture integrated over the depths of 0-6, 0-12 and 0-20 cm were carried out at the daily timescale for approximately one month during summers 2005, 2006 and 2007 (Table 2) at several locations on two hillslopes (Piramide and Emme) at BCC, and one hillslope (Vallecola) downstream the BCC outlet. Continuous soil moisture measurements were also carried out at different locations at LCC in years 2007-2009 and at BCC in years 2005-2006 and 2010-2013 to analyze the role of soil moisture on runoff generation. Soil moisture probes were installed along transects; particularly, a riparian-hillslope transect was set up for the 2010-2013 measurements at BCC (Penna et al., 2016).

The dynamics of shallow groundwater were also investigated at both LCC and BCC by several piezometers installed to a depth-to-refusal. At BCC, piezometers were installed on two hillslopes (Piramide and Emme) in years 2008-2010 and along three transversal transects (hillslope-riparian-hillslope) in the lower part of the catchment in years 2011-2013. Data from piezometers located in Piramide and Emme hillslopes were used to assess the role of topography, soil depth and shape of the hillslopes in the variability and timings of shallow subsurface flow generation (Penna et al., 2015). Depths to water table data from LCC and the hillslope-riparian-hillslope transects in BCC were also used to quantify subsurface connectivity by a graph-theory approach (Phillips et al., 2011) and to study the effects of rainfall-runoff events and topographic characteristics on connectivity (Zuecco et al., in review). 


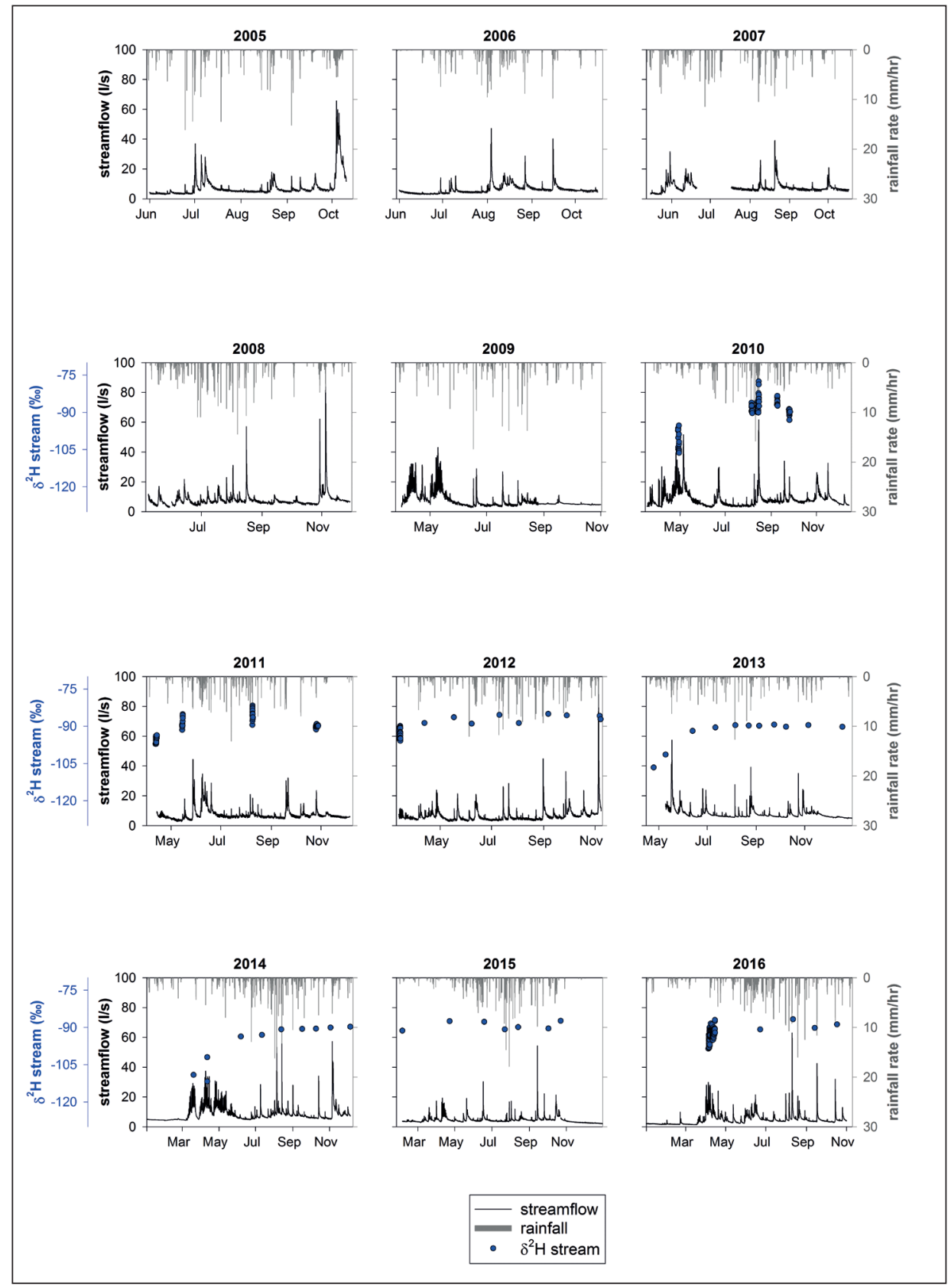

Figure 2. Hydrograph and stream isotopic composition $\left(\delta^{2} H\right)$ at BCC for the available years. 
Table 2. Hydro-meteorological data available for each subcatchment with specific period and brief description of the sampling design. TDR: Time Domain Reflectometry; FDR: Frequency Domain Reflectometry.

\begin{tabular}{|c|c|c|c|}
\hline $\begin{array}{c}\text { Hydro- } \\
\text { meteorological } \\
\text { variable }\end{array}$ & $\begin{array}{c}\text { Subcatchment } \\
\text { (elevation in parenthesis) }\end{array}$ & Period & Sampling design \\
\hline \multirow{4}{*}{ Precipitation } & ChB (2868 m a.s.1.) & Jun-Oct since 2009 & \multirow{4}{*}{$\begin{array}{l}\text { Approx. one rain gauge/ } \\
\text { subcatchment, recording at 15- } \\
\text { min interval }\end{array}$} \\
\hline & $\operatorname{RVC}(2566$ and $2553 \mathrm{~m}$ a.s.1.) & May-Oct since 2008 & \\
\hline & LCC (2030 m a.s.1.) & May-Oct 2007-2009 & \\
\hline & BCC (1940 m a.s.1.) & May-Oct since 2005 & \\
\hline \multirow{5}{*}{ Stream stage } & ChA (2657 m a.s.1.) & $\begin{array}{l}\text { All year round since } \\
2009\end{array}$ & \multirow{5}{*}{$\begin{array}{l}\text { One stream gauge/ } \\
\text { subcatchment located at (or } \\
\text { close to) the outlet, recording at } \\
15 \text {-min interval (or } 30-\text { min in } \\
\text { winter). Rating curves available } \\
\text { for LCC and BCC }\end{array}$} \\
\hline & ChB (2647 $\mathrm{m}$ a.s.1.) & $\begin{array}{l}\text { All year round 2011- } \\
2016\end{array}$ & \\
\hline & LCC (1974 m a.s.l.) & May-Oct 2006-2013 & \\
\hline & BCC (1932 m a.s.1.) & $\begin{array}{l}\text { May-Oct 2005-2012; } \\
\text { all year round since } 2013\end{array}$ & \\
\hline & RVC (1888 m a.s.l.) & $\begin{array}{l}\text { All year round since } \\
2012\end{array}$ & \\
\hline \multirow{5}{*}{ Soil moisture } & \multirow[b]{2}{*}{ LCC } & May-Oct 2007-2010 & $\begin{array}{l}4 \text { TDR probes at } 4 \text { locations } \\
\text { installed at } 0-30 \mathrm{~cm} \text { depth, } \\
\text { recording at } 15 \text {-min interval }\end{array}$ \\
\hline & & May-Oct 2007-2009 & $\begin{array}{l}\text { Monthly manual measurements } \\
\text { by impedance and TDR probes } \\
\text { at } 0-6,0-12 \text { and } 0-20 \mathrm{~cm} \text { depth } \\
\text { at } 64 \text { locations }\end{array}$ \\
\hline & \multirow{3}{*}{$\mathrm{BCC}$} & $\begin{array}{l}\text { Jun-Jul 2005-2006 } \\
\text { Aug-Sep } 2007\end{array}$ & $\begin{array}{l}\text { Daily manual measurements by } \\
\text { impedance and TDR probes at } \\
0-6,0-12 \text { and } 0-20 \mathrm{~cm} \text { depth at } \\
78 \text { locations }\end{array}$ \\
\hline & & May-Oct 2005-2006 & $\begin{array}{l}4 \text { TDR probes at } 4 \text { locations } \\
\text { installed at } 0-30 \mathrm{~cm} \text { depth, } \\
\text { recording at } 1 \text {-hour interval }\end{array}$ \\
\hline & & Jun-Oct 2010-2013 & $\begin{array}{l}15 \text { FDR probes at } 6 \text { locations, } \\
\text { horizontally installed at } 5,20 \\
\text { and } 40 \mathrm{~cm} \text { depth, recording at } \\
15 \text {-min interval }\end{array}$ \\
\hline \multirow{4}{*}{$\begin{array}{l}\text { Depth to water } \\
\text { table }\end{array}$} & LCC & May-Oct 2007-2013 & $\begin{array}{l}\text { Up to } 13 \text { piezometers equipped } \\
\text { with capacitance sensors } \\
\text { recording at } 15 \text {-min interval }\end{array}$ \\
\hline & \multirow{3}{*}{$\mathrm{BCC}$} & May-Oct 2008-2010 & $\begin{array}{l}\text { Up to } 24 \text { piezometers equipped } \\
\text { with capacitance sensors, } \\
\text { recording at } 15 \text {-min interval }\end{array}$ \\
\hline & & May-Oct 2011-2013 & $\begin{array}{l}\text { Up to } 18 \text { piezometers equipped } \\
\text { with capacitance sensors and } \\
\text { pressure transducers, recording } \\
\text { at } 15 \text {-min interval }\end{array}$ \\
\hline & & $\begin{array}{l}\text { All year round since } \\
2014\end{array}$ & $\begin{array}{l}4 \text { piezometers equipped with } \\
\text { pressure transducers, recording } \\
\text { at } 15 \text {-min interval }\end{array}$ \\
\hline
\end{tabular}




\subsection{Hydrological tracers}

The use of hydrological tracers started in 2010 to complement the acquisition of hydrometric measurements, with the main objective to identify and quantify streamflow components and to infer runoff flow pathways. The stable isotopes of water $\left({ }^{2} \mathrm{H}\right.$ and $\left.{ }^{18} \mathrm{O}\right)$ were chosen as tracers for their conservative behaviour (Vitvar et al., 2005), and electrical conductivity (EC) was selected as additional, low cost tracer considered as proxy of solute concentration. Samples from tracer analysis were mainly collected from different water sources at BCC and lower RVC (2010-ongoing) and, less intensively, at ChA, ChB and upper RVC (2011-2013). Samples from the following water sources were taken at different locations: rainfall, fresh snow, snowpack, snowmelt, soil water, shallow groundwater, spring water, stream water during baseflow and stream water during selected rainfall-runoff and snowmelt-runoff events. Rain-on-snow events play an important role on the hydrological response of mountain headwater catchments (Cohen et al., 2015; Juras et al., 2016). Unfortunately, it was not possible to collect samples for tracer analysis during rain-on-snow events.

Rainfall was sampled in collectors equipped with a funnel and a layer of mineral oil to minimize evaporation; snowpack was sampled through snow cores; snowmelt by means of $1-\mathrm{m}^{2}$ snowmelt lysimeters; mobile soil water by means of suction cups, and groundwater was sampled in the shallow piezometers. Fresh snow, spring water and stream water were sampled directly. Sampling locations in the catchment are depicted in the maps reported in previous works (Penna et al., 2016, 2017). Samples for isotopic analysis and EC were manually collected from the different water sources using $50 \mathrm{ml}$ high-density plastic bottles with a double cap, were stored at $4^{\circ} \mathrm{C}$ and were analysed as soon as possible. The isotopic composition was determined by off-axis integrated cavity output spectroscopy (OA-ICOS) following the procedures to increase accuracy and mitigate memory effects reported in Penna et al. (2010a; 2012). The typical instrumental precision (average standard deviation of 2094 samples) was $0.5 \%$ ofor $\delta^{2} \mathrm{H}$ and $0.08 \%$ for $\delta^{18} \mathrm{O}$.

\section{Hydrological behaviours and runoff generation processes}

\subsection{Tracer signature in different water compartments}

Different water compartments sampled in the catchment show distinct tracer signature and large spatial and temporal variability. Tracer data collected over seven years at BCC show how precipitation is the most variable source in isotopic composition (due to seasonal effect, but also to the intrinsic variability during rainfall events, cf. McDonnell et al. (1990)) followed by snowmelt (more depleted in heavy isotopes) and soil water (Fig. 3a). The isotopic composition of spring water at two locations, shallow groundwater at two locations and stream water are less variable and with similar median values, suggesting similar spatial origin of these water sources (Fig. 3a). Conversely, rain water has an extremely low variability in EC and soil water and groundwater have a very large variability in EC (Fig. 3b). Particularly, spring water and shallow groundwater are more variable in EC than in isotopic composition suggesting complex subsurface hydrochemical interactions in this catchment. 


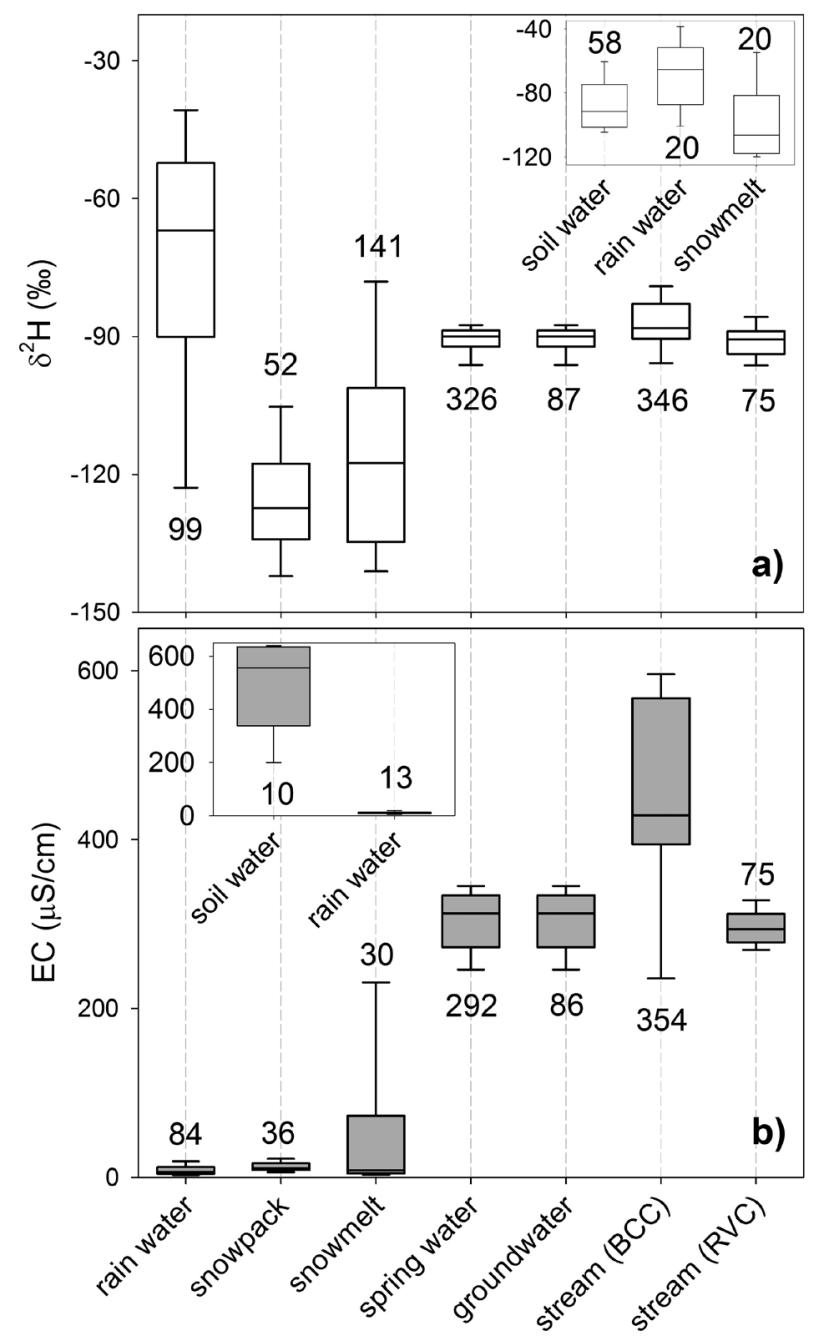

Figure 3. Box plots of $\delta^{2} H(a)$ and $E C(b)$ in different water sources sampled at BCC and RVC between 2010 and 2016. The insets show the tracer composition of soil water and precipitation sampled on the same days between May and October. The boxes indicate the 25th and 75th percentile, the whiskers indicate the 10th and 90th percentile, the horizontal line within the box marks the median. The numbers above or below the boxes indicate the number of samples.

An example of the large temporal variability of tracer signature is shown for two rainfall-runoff and two snowmelt-runoff sampled at BCC (Fig. 4). The isotopic composition of rain water and stream water during storms can vary up to $45 \%$ and $17 \%$ o in $\delta^{2} \mathrm{H}$, respectively (Fig. 4a), and $\mathrm{EC}$ of stream water can vary up to $65 \mu \mathrm{S} \mathrm{cm}^{-1}$ (Fig. 4b). Snowmelt isotopic composition during individual melt events can be also quite variable, although less than rainfall, and up to $17 \%$ in $\delta^{2} \mathrm{H}$ (data reported in Penna et al., 2016). 


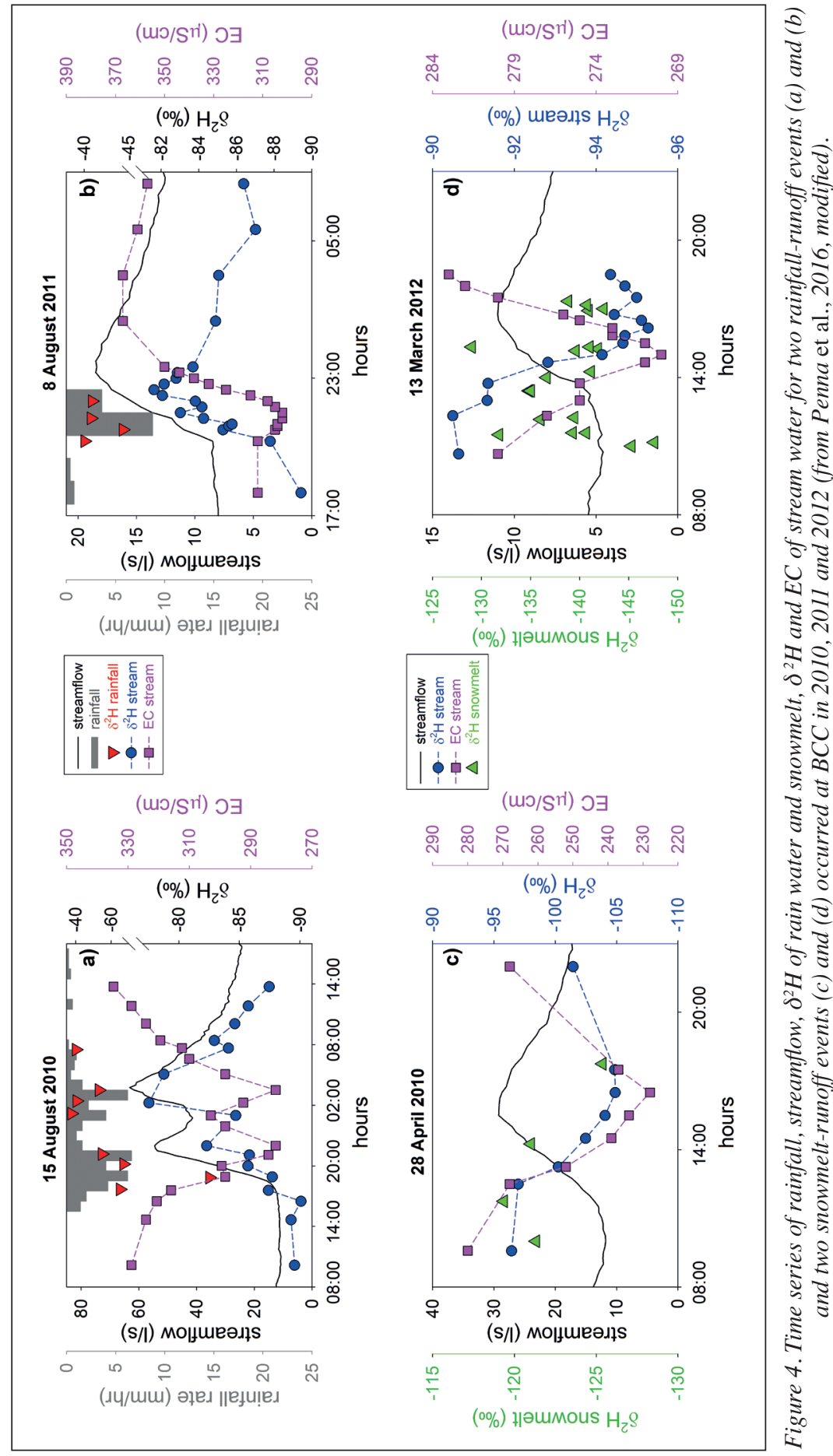




\subsection{Hydrological thresholds}

Non-linear behaviours are common in geomorphic and hydrological systems. According to the definition by Phillips (2006), a system is non-linear if the outputs (or responses or outcomes) are not proportional to the inputs (or stimuli, changes, or disturbances) across the entire range of the latter. Thresholds and hysteresis are typical examples of non-linearity (the latter is described in Section 4.3). In simple terms, a threshold is defined as the point at which a system's behaviour evolves to a "critical" state and changes (Phillips, 2003, 2006). In hydrological systems, threshold behaviours have been typically described as changes in runoff response disproportional to forcing inputs across the whole possible range of inputs (Ali et al., 2015). Threshold behaviours in catchment hydrology have been observed in a variety of environments and climatic conditions, reflecting the interplay between climate, soil, vegetative, geological and biogeochemical conditions. As such, thresholds can be used as a classification tool to better conceptualize how runoff response behaves under a range of conditions (Ali et al., 2013, 2015). Moreover, thresholds have been found in the relationship between different variables, including soil moisture and streamflow (e.g., Zehe et al., 2010; Radatz et al., 2013), soil moisture and runoff ratios (James and Roulet, 2007), soil moisture and shallow groundwater (Latron and Gallart, 2008), subsurface stormflow and rainfall (Tromp-van Meerveld and McDonnell, 2006a, 2006b; Detty and McGuire 2010a, 2010b), runoff ratios and precipitation intensity (Lehmann et al., 2007; Radatz et al., 2013), and a combination of antecedent soil moisture plus rainfall and stormflow (Detty and McGuire 2010a, 2010b; Fu et al., 2013; Farrick and Branfireun, 2014).

Different types of hydrological thresholds have been observed and described at RVC and its subcatchments. Data collected in 2007 at LCC showed a clear threshold response between soil moisture and streamflow, revealing the important role of initial moisture conditions in determining the extent of the saturated near-stream area and controlling the runoff production of the entire catchment (Penna et al., 2010b). At BCC, 40 rainfall-runoff events were selected during two June-October monitoring periods in 2005 and 2006 (Penna et al., 2011). The relationship between the average soil moisture measured at $0-30 \mathrm{~cm}$ at four locations on a hillslope before the storm onset and the runoff ratios for these events identified a clear soil moisture threshold value (approximately 45\%) above which runoff noticeably increased (Fig. 5a). Moreover, the same threshold was found in the relation between antecedent soil moisture at 0-30 cm and streamflow, and between antecedent soil moisture at 0-30 $\mathrm{cm}$ and shallow groundwater, indicating a strong influence exerted by wetness conditions on both surface and subsurface response (Penna et al., 2011). Interestingly, we observed that most of the small runoff ratios below the soil moisture threshold were smaller than 0.09 (or $9 \%$, Fig. 5a) which corresponds very well with the size of the riparian zone (8.6\%). This indicates that during dry antecedent soil moisture conditions runoff was mainly generated in the wetter riparian zone and produced low runoff ratios, whereas during wet periods and larger rainfall events, the most significant contribution to streamflow came from hillslopes, which became hydrologically connected to the stream once the soil moisture threshold was exceeded (Penna et al., 2011). These results obtained at BCC by hydrometric data were confirmed by isotopic and EC tracers sampled during selected rainfall-runoff and snowmelt-runoff events. Particularly, EC dynamics and end-member mixing analysis (Christophersen et al., 1990; 
Hooper et al., 1990), combined with soil moisture and shallow water table data revealed that during dry conditions riparian groundwater contributed little to the rise in streamflow and with a delayed response (because rainfall initially had to fill the storage). Conversely, during wet conditions, the contribution of riparian groundwater to stream runoff was faster and larger, coupled with subsurface runoff from an increasingly larger portion of the hillslope zone as wetness conditions increased (Penna et al., 2016). Moreover, the application of isotope-based two-component hydrograph separation techniques (Pinder and Jones, 1969; Sklash and Farvolden, 1979) to nine rainfall-runoff events and six snowmelt-runoff events revealed maximum contributions of event water up to $37( \pm 38) \%$ and $46( \pm 16) \%$ of the total streamflow during large rainfall and snowmelt events, respectively, revealing a dominance of pre-event water even during very wet conditions (Penna et al., 2016).

The analysis of 63 rainfall-runoff events occurred at BCC in 2008, 2009 and 2010 also revealed the existence of a threshold relation between stormflow and the sum of an antecedent soil moisture index expressed in mm (ASI, Haga et al., 2005) and event rainfall amount (Fig. 5b). This reveals an important combined effect of precipitation amount and antecedent soil moisture on the hydrological response of BCC. Moreover, this threshold behaviour, in combination with the observation that in wet conditions water table measured in the hillslope piezometers was higher than in dry conditions but without reaching the soil surface, indicates that during wet periods (e.g., for events above the threshold) the rainfall input triggered the formation of subsurface flow that noticeably contributed to the total catchment runoff (Penna et al., 2015). The combined effect of precipitation depth and antecedent soil moisture on runoff production is exemplified in the threshold relation between rainfall and stormflow (Fig. 6). Large stormflow amounts were produced during wet conditions (see inset of Fig. 6 ), and a marked increase in stormflow was recorded when both precipitation amount and antecedent soil moisture increased. However, a clear threshold in the relation between stormflow and rainfall did not exist for events with wet antecedent condition, and stormflow increased almost linearly with rainfall.

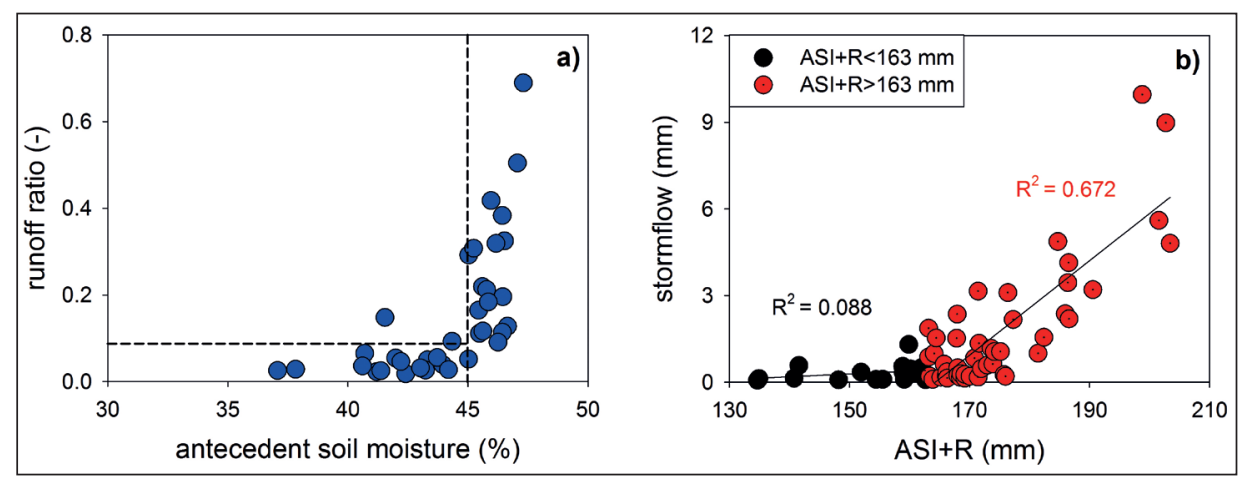

Figure 5. a) Threshold relation between antecedent soil moisture at 0-30 cm depth and runoff ratio for 40 rinfall-runoff events occurred at BCC (from Penna et al., 2011, modified). The dashed lines represent the runoff ratio corresponding to the $45 \%$ antecedent soil moisture value. $b$ ) Threshold relation between antecedent soil moisture index (ASI) and rainfall $(R)$, and stormflow for 63 rainfall-runoff events occurred at BCC (from Penna et al., 2015, modified). 


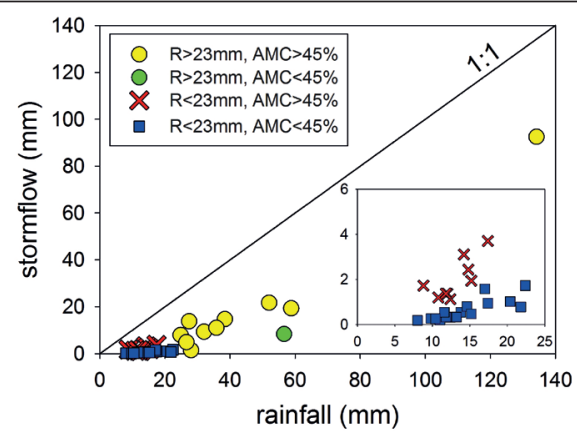

Figure 6. Relation between rainfall and stormflow for 40 rainfall-runoff events occurred at BCC (from Penna et al., 2011, modified). " $R$ " stands for "rainfall" and "AMC" stands for "average antecedent moisture content" measured at 0-30 cm. In the inset: zoom for the relation at low rainfall values.

\subsection{Hysteresis}

Hysteresis is a non-linear behaviour where two or more values of a dependent variable are associated with a single value of an independent variable (Phillips, 2003). Hysteretic loops are often related to the occurrence of a time lag between two variables (Prowse, 1984). Indeed, several studies have reported hysteretic relations between streamflow and other variables, such as sediment (e.g., Lawler et al., 2006; Aich et al., 2014) and solute concentrations (e.g., Evans and Davies, 1998; Butturini et al., 2006; Aubert et al., 2013; Lloyd et al., 2016a), subsurface hillslope flow (e.g., McGuire and McDonnell, 2010), storage (e.g., Davies and Beven, 2015; Pfister et al., 2017) and groundwater levels (e.g., Allen et al., 2010; Fovet et al., 2015). In the last two decades, both the qualitative interpretation of hysteresis (e.g., Evans and Davies, 1998) and the application of quantitative metrics (e.g.,Aich et al., 2014; Lloyd et al., 2016b; Zuecco et al.,2016) for the description of the loops improved the knowledge of the mechanisms triggering runoff generation and displacement of sediments and contaminants.

In our research studies of the functional mechanisms determining runoff generation at BCC and LCC, we have observed a number of hysteretic relations at the runoff event timescale between streamflow and variables such as soil moisture, depth to water table and EC of stream water (Fig. 7). By means of an analysis of response times of streamflow, soil moisture and depth to water table to rainfall events, we found that lags between streamflow and soil moisture lead to hysteretic relations between the two variables (Penna et al., 2011). Particularly, we observed that streamflow peaking before hillslope soil moisture determined an anti-clockwise relation (streamflow as independent variable in the bivariate plot; Fig. 7a), which was typical of dry antecedent conditions (antecedent moisture conditions $<45 \%$, Fig. 5a). Conversely, soil moisture peaked before streamflow during events with wet antecedent moisture conditions $(>45 \%)$ and this lag led to clockwise loops (Fig. 7b). Similar results were found in the relation between streamflow and hillslope soil moisture, which varied seasonally and depended on total rainfall amount (Zuecco et al., 2016). Changes in the direction of the hysteretic loop based on wet and dry periods likely indicate that shallow soil layers at BCC contribute to runoff when they are more humid or when a threshold in soil moisture is exceeded. 

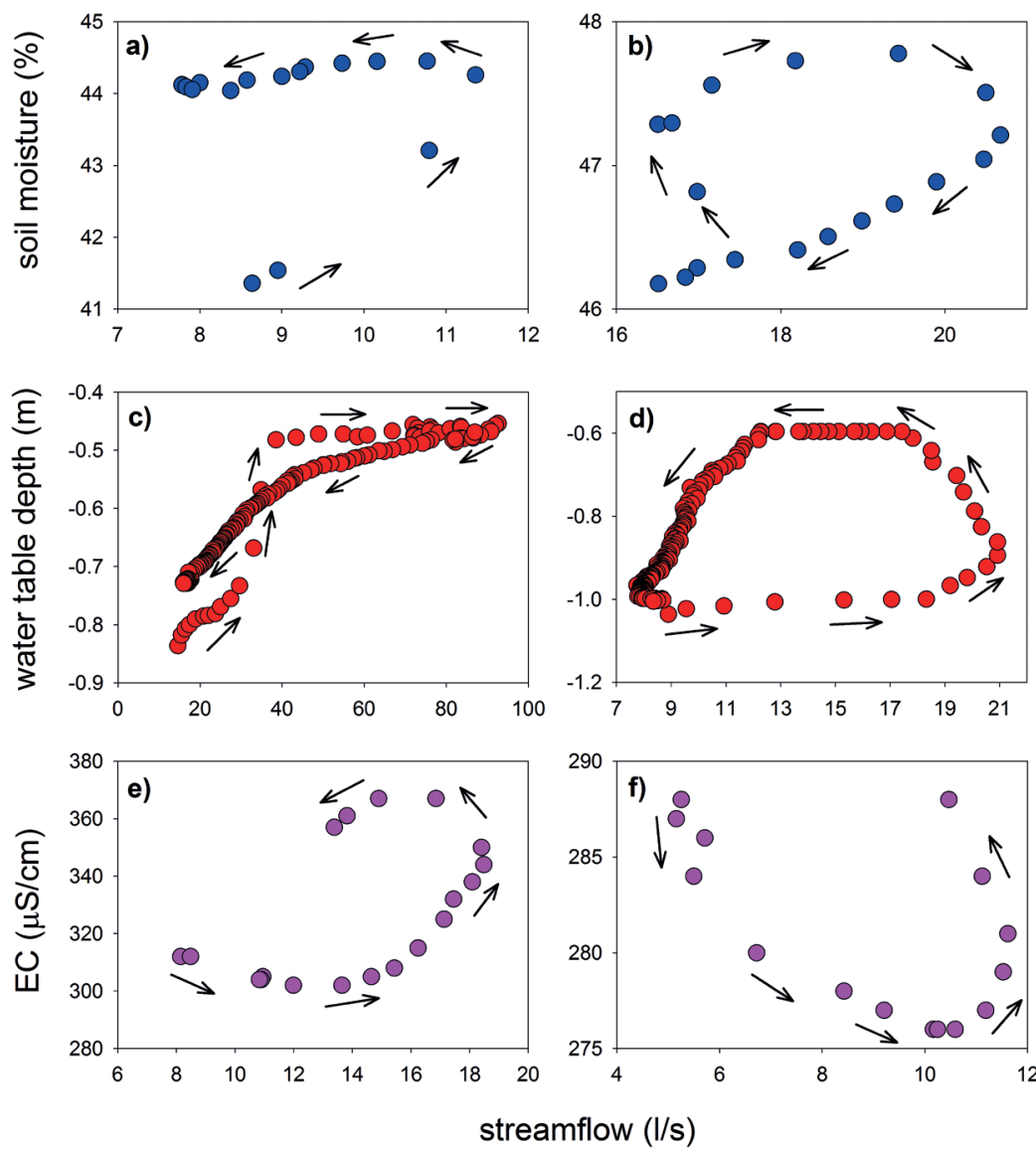

Figure 7. Example of hysteresis loops in the relation between streamflow and soil moisture (top row), water table depth from the soil surface (middle row) and electrical conductivity (bottom row) for different rainfall events at BCC. a) 14 October 2006; b) 16 September 2006; c) 4 November 2012; d) 5 August 2011; e) 8 August 2011;f) 14 March 2011. The arrow indicates the direction of the loop (clockwise, anticlockwise, eight shape).

Hysteretic loops were also evident in the relation between streamflow and depth to water table at BCC (Fig. 7c, d) and LCC. For BCC, we found that the average response of the water table measured on Piramide and Emme hillslopes generally lagged behind streamflow, and time lags between water table and streamflow peak were related to soil depth and topographic position of the piezometers (Penna et al., 2015). The delay of groundwater response compared to streamflow resulted in anti-clockwise hysteresis (Fig. 7d). The more common anti-clockwise direction supports the hypothesis that at the beginning of rainfall events the increase in streamflow is determined by direct channel precipitation or overland flow from near-stream saturated areas (Penna et al., 2016). Clockwise loops and complex-shaped loops with a water table peak preceding 
streamflow peak were rarely found and were more typical of large rainfall events and/ or wet moisture conditions. Other studies analysed the temporal and spatial variation of hysteresis (e.g., Detty and McGuire, 2008; McGuire and McDonnell, 2010) highlighting the role of hillslopes in runoff generation during wet periods and for large rainfall events (Ocampo et al., 2006; von Freyberg et al., 2014). At LCC, we observed similar hysteretic relations between depth to water table and streamflow. We analyzed and modelled these hysteretic patterns finding that water table on the hillslopes had a slower response than both streamflow and water table in the riparian zone (Camporese et al., 2014). This implies that the water table in the riparian zone becomes active before the water table on the hillslopes, revealing a fundamental role of topography on runoff generation processes.

Our hypothesis that at the beginning of rainfall events direct channel precipitation and overland flow from near-stream saturated areas determine an increase in stream runoff in BCC was confirmed by the analysis of stream water EC dynamics. For both rainfall and snowmelt events we observed a decrease in stream water EC occurring during the rising limb of the hydrograph and usually before the streamflow peak, followed by an increase of stream water EC, reaching values similar to or much larger than stream water EC before the start of the event (Penna et al., 2016). While we hypothesize that the drop in stream water EC is due to direct channel precipitation and overland flow from nearstream saturated areas (they tended to have low EC values; e.g., rain water in Fig. 3b), we relate the increase in stream water EC to the activation of subsurface flow from both the riparian zone and/or the hillslopes (indeed, groundwater had larger EC values than stream water; Fig. 3b). This response led to hysteretic loops between streamflow and stream water EC (Fig. 7e, f). Anti-clockwise loops between streamflow and stream water EC denote that the EC minimum is usually reached before the streamflow peak, and then EC starts to increase reaching its maximum during the falling limb of the hydrograph, but when streamflow values are still larger than before the start of the event.

\subsection{Connectivity}

\subsubsection{Hillslope-riparian-stream connectivity}

Hydrologic connectivity is a concept of great interest in hydrology and geomorphology, but still lacking a common definition (Bracken et al., 2013). In general, hydrologic connectivity describes the movement of water from one part of the landscape to another (Bracken and Croke, 2007). The linkage of separate areas of a catchment can develop via either surface or subsurface flow (Blume and van Meerveld, 2015). Connectivity can also be defined as the hydrological connection between the riparian zone and the hillslopes when the water table is above a confined layer (Jencso et al., 2009). Field methods used for the analysis of hydrologic connectivity can be divided into hillslope-centered methods, focusing on the movement of water through a hillslope, and stream-centered methods, investigating the tracer signature of hillslope water in the stream (Blume and van Meerveld, 2015).

For both BCC and LCC, we used a hillslope-centered approach based on the network of piezometers installed in 2011-2012 and 2009-2010 in BCC and LCC, 
respectively (Fig. 8). For each of the catchments we used flow directions obtained from Digital Terrain Models to build a graph theory network consisting of nodes (piezometers) and edges linking piezometers to the stream network (Zuecco et al., in review). This approach allowed us to quantify the subsurface connectivity for the lower part of the two catchments and to identify the main controls on connectivity (e.g., rainfall-runoff event characteristics and topographic features). During rainfall-runoff events at BCC and LCC, the maximum connectivity was positively and significantly $(\mathrm{p}<0.05)$ correlated to direct runoff and the sum of precipitation and antecedent precipitation, while rainfall intensity and antecedent precipitation could not be used as predictors of subsurface connectivity. Specifically, threshold relations were found between maximum connectivity and direct runoff and between maximum connectivity and sum of precipitation and antecedent precipitation. These threshold relations indicate that for small events and dry antecedent wetness conditions, a smaller part of the catchment is connected to the stream and direct runoff volumes are small. Conversely, when a threshold sum of precipitation and antecedent precipitation is reached, more piezometers become connected to the stream network and therefore contribute to runoff. We suppose that before reaching the threshold, only the water table in the riparian zone sustains runoff, and when the threshold is exceeded hillslope subsurface flow starts contributing to stream runoff. These results are consistent with previous research at LCC (Camporese et al., 2014), BCC (Penna et al., 2015) and other mountain catchments (Jencso et al., 2009; Detty and McGuire, 2010a, b). Fractions of time that piezometers were connected to the stream (Fig. 8) were found to be positively correlated to topographic wetness index of contributing areas located upslope of the piezometers in LCC and negatively correlated to overland flow distance of piezometers from the stream network at BCC (Zuecco et al., in review). The larger duration of connected piezometers in the riparian zone of BCC compared to hillslope piezometers corroborates the tracer-based investigations on the role of subsurface flow during runoff events at BCC (Penna et al., 2016).

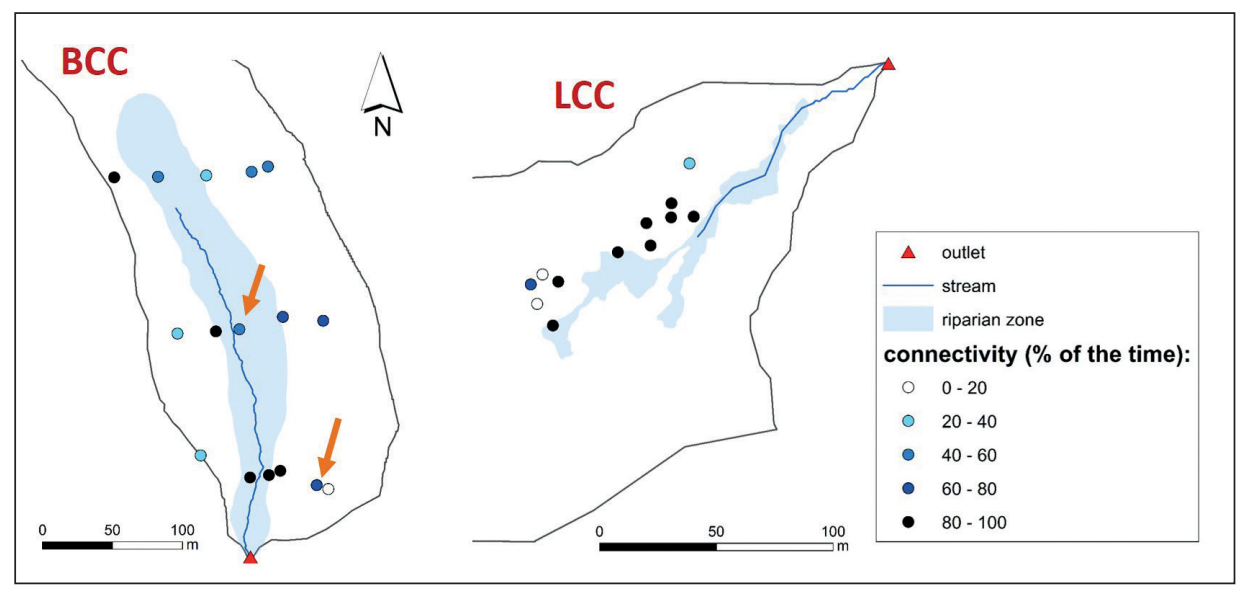

Figure 8. Duration of connectivity (fraction of time that piezometers were connected to the stream relative to the total measurement time) in BCC and LCC. The total measurement time is about the period May-October 2011-2012 in BCC and May-October 2009-2010 in LCC. Arrows indicate gatekeeper sites. 


\subsubsection{Upper-lower catchment connectivity}

End-member mixing analysis (EMMA) can be considered as a stream-centered method to assess hydrologic connectivity. At BCC, mixing plots between EC and $\delta^{2} \mathrm{H}$ showed that pre-event stream water, event water (rainfall or snowmelt) and groundwater defined a mixing space for stream water samples collected during runoff events (Penna et al., 2016). Although we found that tracer composition of groundwater varies strongly both in space and time, mixing plots and hydrograph separation suggested that stream water has a tracer signature similar to groundwater and pre-event water is the main contributor to runoff generation. Stream water EC dynamics highlighted that after a dilution effect due to direct channel precipitation or overland flow from near-stream saturated areas, areas of BCC with subsurface waters having large EC values became connected to the stream and contributed to the increase in stream water EC. Our hypothesis of subsurface connectivity based on stream water EC dynamics was supported by observing that the increase in stream water EC occurred at the same time as or later than the increase of the water table in four piezometers (Penna et al., 2016).

Collection of tracer data at different locations of RVC allowed us to compare the tracer signature of stream water across an elevation gradient, and identify the main end-members to stream runoff (Fig. 9; Penna et al., 2017). While $\delta^{2} \mathrm{H}$ of rocky channel runoff and springs in $\mathrm{ChA}$ and $\mathrm{ChB}$ had a large variability ranging from the signal of snowmelt and that of rain water, spring and stream water of BCC and lower RVC had a damped variability in isotopic composition and were more similar to groundwater. EC of waters sampled in the rocky subcatchments was low and particularly similar to snowmelt EC. Conversely, spring and stream water EC measured in soil-mantled catchments had large values confirming similarity to groundwater EC. An overlap between the two distinct groups of channel runoff and spring samples from ChA and $\mathrm{ChB}$, and stream and spring water samples from lower RVC was determined by some samples of stream water collected in the lower RVC during the snowmelt periods (Fig. 9). The mixing space highlighted that the rocky subcatchments were recharged mainly by event-water contribution (i.e., snowmelt), while BCC and lower RVC were characterized by large pre-event water contributions (Penna et al., 2017). Our current results let us suppose that understanding the hydrologic connectivity between the upper and lower catchment is complex and hampered by the presence of different aquifers. However, our first results showed that different portions of RVC (i.e., the rocky and the soil-covered parts) have waters with distinct tracer signatures, which mix along the main channel network, and therefore determine the hydrological connection between the upper and lower part of RVC. Moreover, based on results obtained by the examination of fractions of young water in catchments at the global scale and in Canada (Jasechko et al., 2016, 2017, respectively), we would expect larger fractions of young water in the less steep, soil-mantled BCC and LCC compared to the steeper, upper subcatchments of RVC (e.g., Fig. 4). However, our data do not currently allow for a solid computation of young streamflow fractions in the different portions of RVC, and further investigations are needed for this purpose. 


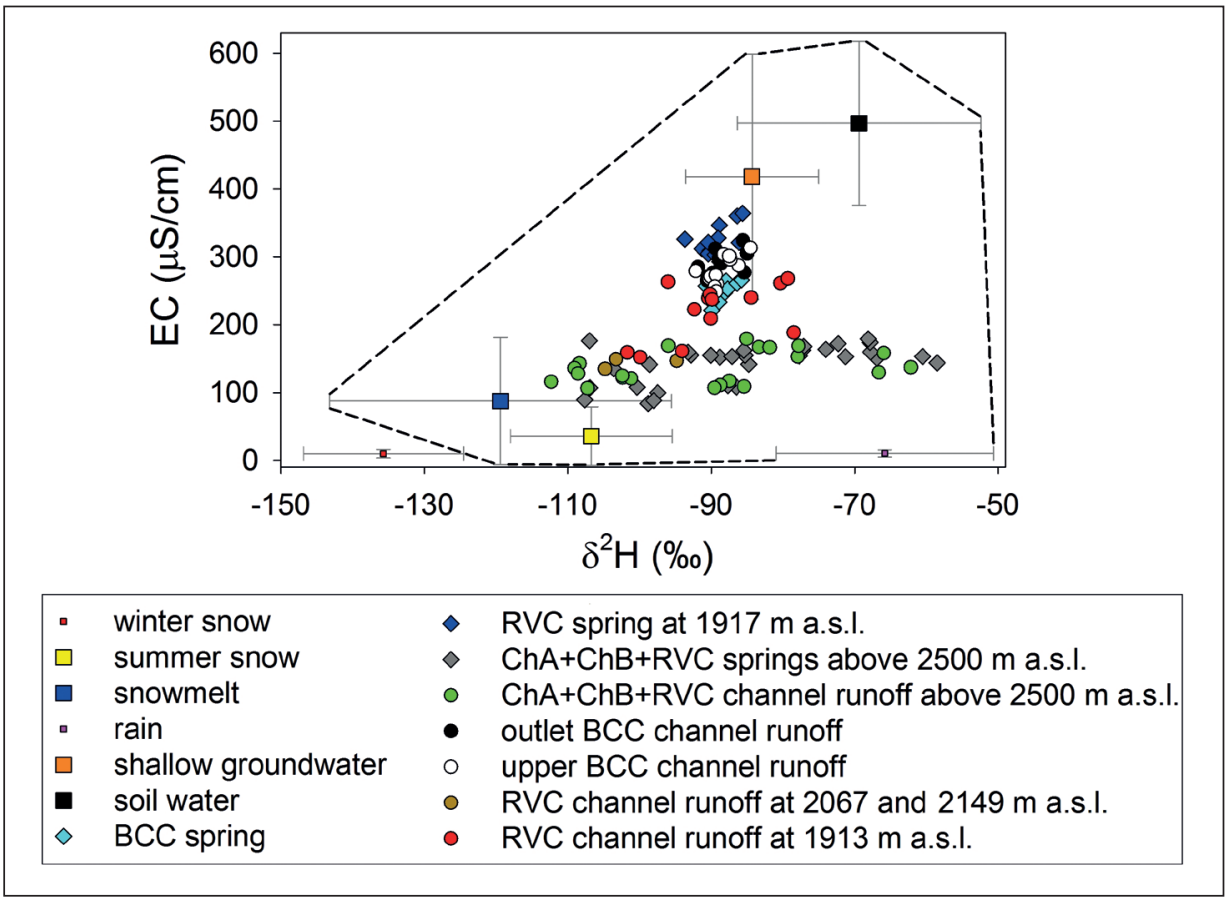

Figure 9. Mixing-plot of $\delta^{2} H$ vs. EC for different water sources sampled at ChA, ChB, BCC and RVC in the period June to October 2011-2013 during no-rainy conditions. Soil water, shallow groundwater, snowmelt, summer snow, winter snow and rain water are represented as averages, and error bars indicate the standard deviation. The isotopic composition and EC of rainfall are weighted for the rainfall amount (from Penna et al., 2017).

\section{Summary of runoff generation processes at RVC and future research}

The experimental activities carried out over 12 years in RVC and its subcatchments provided new insights into the hydrological functioning of Dolomitic headwater catchments. The interaction between the harsh topography, the fractured geology and the climatic forcing produces multiple hydrological behaviours, including nonlinearities (thresholds, hysteresis) and highly spatio-temporal dynamic phenomena (expansion of saturated areas, hillslope-riparian-stream connectivity) that lead to a complex internal functioning of this catchment. Long-term and high-resolution hydrometeorological and tracer measurements at nested scales offered a way to unravel part of this complexity and revealed the different controls on the hydrological response of RVC. All these findings contributed to provide a perceptual model of water flow pathways and runoff generation at RVC and its soil-mantled subcatchments (i.e., BCC and LCC) that can be considered representative for many other headwater mountain catchments. Considering the entire RVC and its nested spatial organization, snowmelt, shallow groundwater and soil water were found to be the main contributors to stream runoff and spring recharge, but with different relative importance in the different parts of the 
catchment. Soil water and shallow groundwater are the dominant end-members in the soil-mantled subcatchments whereas rainfall and snowmelt play a more direct role on stream runoff and spring water in the upper part of RVC, characterized by rocky areas. A weak hydrochemical interaction between water input (rainfall and snowmelt) and soil and rocks, and little and relatively fast subsurface runoff exist in the rocky subcatchments of RVC, characterized by waters with low EC and highly variable isotopic composition. Conversely, rainfall and snowmelt are likely characterized by longer residence times in the lower parts of RVC and in its soil-mantled subcatchments, and represent important sources for baseflow and shallow groundwater recharge. These findings, coupled to hydrometric data and geological observations, suggest the existence of two main water circulation systems at RVC that are hydrologically connected through the principal channel. There is a likely presence of a smaller and faster aquifer in the upper part of the catchment, and a deep and slow subsurface flow component in the lower part, responsible for stronger hydrochemical interactions between shallow subsurface water and soil (Penna et al., 2017).

The main processes generating streamflow in the soil-mantled subcatchments of $\mathrm{RVC}$, as BCC, where topography is characterized by steep slopes and a narrow riparian zone, include direct channel precipitation, saturation overland flow from the riparian zone, and shallow subsurface flow from the riparian zone and the hillslopes (Fig. 10). Channel precipitation and saturation overland flow onto saturated riparian areas provide the most important contribution to streamflow during dry conditions. This was revealed by i) the observed decrease of stream EC during the initial parts of rainfall events; ii) the increase of event water fractions in streamflow (as inferred from two-component hydrograph separation based on water isotopes) at approximately the same time of the EC decrease; and iii) the correlation between the magnitude of the EC decrease and the average event water contribution during this first part of the streamflow response (Penna et al., 2016). During dry antecedent moisture conditions, shallow subsurface flow develops mainly in the riparian zone, with no or negligible response of hillslope groundwater. This reflects in small runoff ratios and low stormflow values (Fig. 5), and small fractions of event water in the stream (Fig. 10a). Typically, the riparian zone is only partially saturated during dry conditions but saturated areas expand with increasing wetness conditions. Thus, during wet or very wet antecedent moisture conditions, such as large rainfall events or snowmelt events at the peak melting season, overland flow develops on the entire riparian zone. This reflects in higher contributions of event water to the stream (pie chart in Fig. 10b) compared to dry conditions. Moreover, with increasing wetness, shallow subsurface flow develops in an increasing number of riparian and hillslope locations, as shown by response of piezometers, and above a certain threshold a larger area of the catchment contributes to streamflow, leading to a greater runoff production (Fig. 5).

The provided perceptual model shares some similarities with other models of hydrological response in different mountain catchments previously documented in the literature but, at the same time, it shows distinct features and original elements. For instance, findings on the expansion of saturated areas during wet conditions (variable source area concept) and runoff production due to precipitation falling onto them was already presented in the benchmark paper by Hewlett and Hibbert (1967). However, this 
concept only partially agrees with what occurs in our study site, because it did not report (McDonnell, 2003) the mechanisms of threshold behaviour of hillslope activation and the sudden increase in runoff production described at BCC.

Another example of perceptual model of catchment functioning in mountain settings is provided by Inamdar et al. (2013) for a site with humid, continental climate. They found that during wet conditions, groundwater depths were closest to the soil surface and there was considerable mixing and exchange of solutes between the soil and groundwater end-members, whereas when the catchment dried out an increasing level of hydrological decoupling between near-surface soil moisture and groundwater occurred (Inamdar et al., 2013). These findings are analogous to ours. However, these authors noted that in their site, during wet conditions, there was a strong expression of surficial catchment sources whereas we found that during wet conditions water from subsurface sources (mainly from the hillslopes) dominated the hydrograph (Penna et al., 2016).

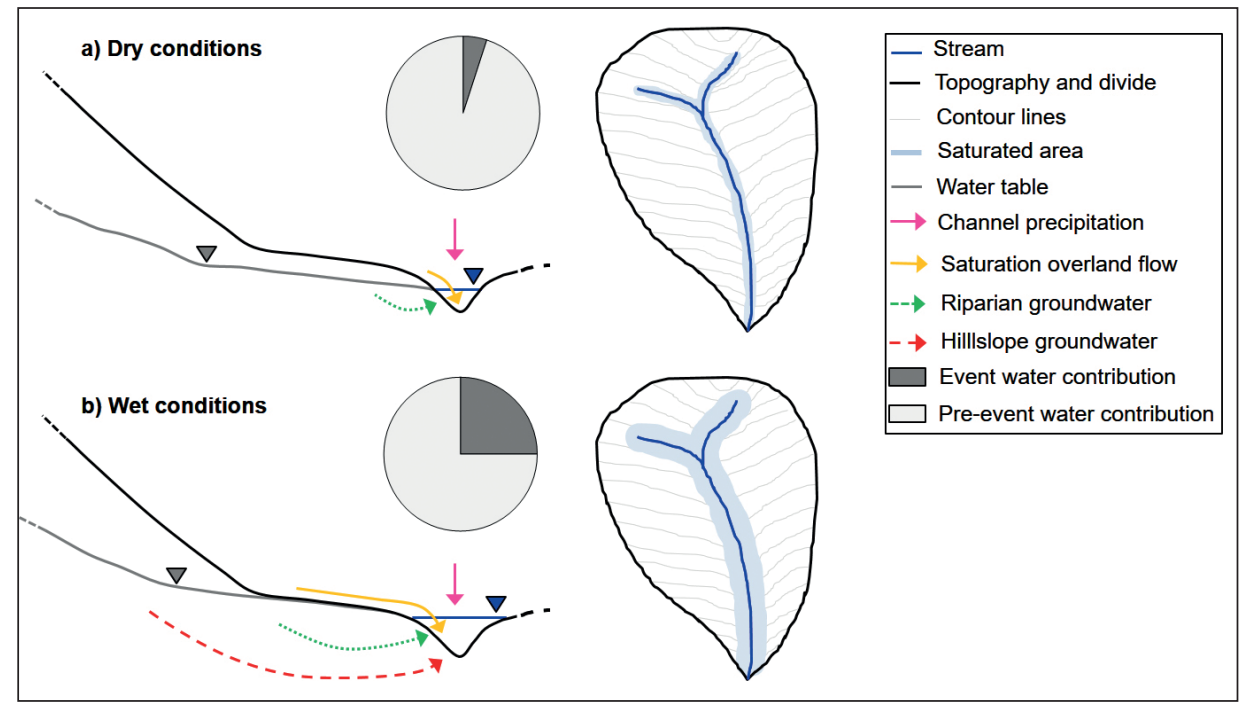

Figure 10. Perceptual model of runoff generation processes at BCC during different wetness conditions. The arrows indicate the water pathways. The longer the arrow, the larger the flux. The pie-charts indicate the typical relative fraction of event and pre-event water in stream water during runoff events. The sketched catchment display the expansion of saturated riparian areas from dry to wet conditions.

Klaus et al. (2015) reported for three forested catchments characterized by hot summers and relatively mild winters that the disconnectivity between the hillslopes and the riparian-stream systems, likely sustained by precipitation and groundwater, was a key element to explain baseflow runoff generation. However, they reported significant degrees of isotopic enrichment in the different water sources, with the slope of the dual isotope regression line decreasing from precipitation, to subsurface stormflow to streamflow, indicating isotopic fractionation and the dominance of evaporation in the water balance (Klaus et al., 2015). This is not in agreement with the isotopic signal 
observed at RVC. Here all water sources show a very limited deviation from the precipitation line, except for shallow soil water, and a slope of the regression line much closer to that of the precipitation line (Penna et al., 2017), indicating that evaporation is not a dominant hydrological process.

All the experimental results obtained at RVC significantly contributed to extend our knowledge of the hydrological functioning of mountain headwater catchments. However, there are still cloudy aspects that need to be clarified and are waiting to be investigated. For instance, we need to better understand: i) the controls on the high spatial variability of the hydrochemical signal of shallow groundwater and, in turn, the role of spatially-variable shallow subsurface flow in different areas of the catchment at different temporal scales; ii) the controls on the temporal variability of hysteretic patterns between streamflow and stream water EC during snowmelt- and rainfall-runoff events by continuous monitoring of groundwater EC; iii) the role of rain-on-snow events on the hydrological response of the catchment through multi-tracer experiments; iv) the role of snowmelt on groundwater recharge and storage at annual time scales by sampling piezometers and bulk soil water over different seasons and years; v) the interplay of hydrogeological controls that determine the connectivity network, regulate water flows and link different aquifers; and vi) the spatial distribution of transit times and their role in governing subsurface water movements through coupled tracer and modelling exercises. All these issues can be more effectively addressed by an integrated experimental (e.g., by multi-tracer tests at high temporal resolution) and modelling approach that can offer more in-depth perspectives on the observed processes. This can help to unravel the intrinsic heterogeneity of these environments and to provide a more detailed and accurate overall view on the hydrological functioning of mountain headwater catchments.

\section{Acknowledgements}

The studies conducted at RVC were financially supported by a number of different projects: the STREP Project HYDRATE, Contract GOCE-037024; the Integrated Project FLOODsite, Contract GOCE-CT-2004-505420; the Research Project GEO-RISKS (University of Padua, STPD08RWBY); the Project "Giovani Studiosi - Ricerche di carattere innovative e di eccellenza proposte da giovani non strutturati, decreto rettorale $n$. 800-2011, 23/03/2011, University of Padua"; the grant "Bando 2014 per il finanziamento di attrezzature scientifiche finalizzate alla ricerca" (University of Padua); and the DIBA NextData Project (Italian Ministry of University and Research).

Moreover, the authors wish to thank Lorenzo Marchi, Marco Cavalli, Stefano Crema (National Research Council (CNR), Research Institute for Geo-Hydrological Protection (IRPI), Padua, Italy) and Sebastiano Trevisani (DACC Department, University IUAV of Venice, Italy) for their work in the upper part of RVC; the Agency for Environmental Protection of Veneto Region (ARPAV) for meteorological data and logistical support; Jeffrey J. McDonnell and Markus Weiler for their useful comments during the initial stage of monitoring; Bepi Crepaz, the land owner of the lower part of BCC; all coauthors and anonymous reviewers of past publications for their valuable contribution; 
many collaborators, bachelor, master and $\mathrm{PhD}$ students who were involved in field work and made the catchment maintenance possible.

\section{References}

Abrahamson, I. 2014. An annotated bibliography of scientific literature on research and management activities conducted in Tenderfoot Creek Experimental Forest. U.S. Department of Agriculture, Forest Service, Rocky Mountain Research Station, Fire Sciences Laboratory, Missoula, MT.

Aich, V., Zimmermann, A., Elsenbeer, H. 2014. Quantification and interpretation of suspendedsediment discharge hysteresis patterns: how much data do we need? Catena 122, 120-129. http://doi.org/10.1016/j.catena.2014.06.020.

Ali, G., Oswald, C.J., Spence, C., Cammeraat, E.L.H., McGuire, K.J., Meixner, T., Reaney, S.M. 2013. Towards a unified threshold-based hydrological theory: necessary components and recurring challenges. Hydrological Processes 27, 313-318. http://doi.org/10.1002/hyp.9560.

Ali, G., Tetzlaff, D., McDonnell, J.J., Soulsby, C., Carey, S., Laudon, H., McGuire, K., Buttle, J., Seibert, J., Shanley, J. 2015. Comparison of threshold hydrologic response across northern catchments. Hydrological Processes 29, 3575-3591. http://doi.org/10.1002/hyp.10527.

Allen, D.M., Whitfield, P.H., Werner, A. 2010. Groundwater level responses in temperate mountainous terrain: regime classification, and linkages to climate and streamflow. Hydrological Processes 24, 3392-3412. http://doi.org/10.1002/hyp.7757.

Amelia, A.A., Amvrosiadib, N., Grabs, T., Laudon, H., Creed, I.F., McDonnell, J.J., Bishop, K. 2016. Hillslope permeability architecture controls on subsurface transit time distribution and flow paths. Journal of Hydrology 543, 17-30. http://doi.org/10.1016/j.jhydrol.2016.04.071.

Aubert, A.H., Gascuel-Odoux, C., Merot, P. 2013. Annual hysteresis of water quality: a method to analyse the effect of intra- and inter-annual climatic conditions. Journal of Hydrology 478, 29-39. http://doi.org/10.1016/j.jhydrol.2012.11.027.

Bailey, S.W., Brousseau, P.A., McGuire, K.J., Ross, D.S. 2014. Influence of landscape position and transient water table on soil development and carbon distribution in a steep, headwater catchment. Geoderma 226-227, 279-289. http://doi.org/10.1016/j.geoderma.2014.02.017.

Benettin, P., Bailey, S.W., Campbell, J.L., Green, M.B., Rinaldo, A., Likens, G.E., McGuire, K.J., Botter, G. 2015. Linking water age and solute dynamics in streamflow at the Hubbard Brook Experimental Forest, NH, USA. Water Resources Research 51, 9256-9272. http://doi. org/10.1002/2015WR017552.

Blume, T., van Meerveld, H.J. 2015. From hillslope to stream: methods to investigate subsurface connectivity. Wiley Interdisciplinary Reviews: Water 2, 177-198. http://doi.org/10.1002/ wat2.1071.

Bosellini, A., Gianolla, P., Stefani, M. 2003. Geology of the Dolomites. Episodes 26, 181-185.

Bracken, L.J., Croke J. 2007. The concept of hydrological connectivity and its contribution to understanding runoff-dominated geomorphic systems. Hydrological Processes 21, 17491763. http://doi.org/10.1002/hyp.6313.

Bracken, L.J., Wainwright, J., Ali, G.A., Tetzlaff, D., Smith, M.W., Reaney, S.M., Roy, A.G. 2013. Concepts of hydrological connectivity: Research approaches, pathways and future agendas. Earth-Science Reviews 119, 17-34. http://doi.org/10.1016/j.earscirev.2013.02.001.

Butturini, A., Gallart, F., Latron, J., Vazquez, E., Sabater, F. 2006. Cross-site comparison of variability of DOC and nitrate c-q hysteresis during the autumn-winter period in three Mediterranean headwater streams: a synthetic approach. Biogeochemistry 77, 327-349. http://doi.org/10.1007/s10533-005-0711-7. 
Camporese, M., Penna, D., Borga, M., Paniconi, C. 2014. A field and modeling study of nonlinear storage-discharge dynamics for an Alpine headwater catchment. Water Resources Research 50, 806-822. http://doi.org/10.1002/2013WR013604.

Carey, S.K., Woo, M. 2001. Slope runoff processes and flow generation in a subarctic, subalpine catchment. Journal of Hydrology 253, 110-129. https://doi.org/S0022-1694(01)00478-4.

Carey, S.K., Quinton, W.L. 2005. Evaluating runoff generation during summer using hydrometric, stable isotope and hydrochemical methods in a discontinuous permafrost alpine catchment. Hydrological Processes 19, 95-114. http://doi.org/10.1002/hyp.5764.

Christophersen, N., Neal, C., Hooper, R.P., Vogt, R.D., Andersen, S. 1990. Modelling streamwater chemistry as a mixture of soilwater end members - a step towards second-generation acidification models. Journal of Hydrology 116, 307-320. http://doi.org/10.1016/00221694(90)90130-P.

Cohen, J., Ye, H., Jones, J. 2015. Trends and variability in rain-on-snow events. Geophysical Research Letters 42. http://doi.org/10.1002/2015GL065320.

Davies, J.A.C., Beven, K. 2015. Hysteresis and scale in catchment storage, flow, and transport. Hydrological Processes 29, 3604-3615. http://doi.org/10.1002/hyp.10511.

Detty, J. M., McGuire, K.J. 2008. Evidence of process complexity and hydrologic threshold responses in a small headwater catchment. In: CUAHSI Biennial Colloquium on Hydrologic Science and Engineering: Resilience and Vulnerability of Natural and Managed Hydrologic Systems, Boulder, Colorado.

Detty, J.M., McGuire, K.J. 2010a. Topographic controls on shallow groundwater dynamics: Implications of hydrologic connectivity between hillslopes and riparian zones in a till mantled catchment. Hydrological Processes 24, 2222-2236. http://doi.org/10.1002/hyp.7656.

Detty, J.M., McGuire, K.J. 2010b. Threshold changes in storm runoff generation at a tillmantled headwater catchment. Water Resources Research 46, W07525. http://doi. org/10.1029/2009WR008102.

Doglioni, C., Carminati, E., 2008. Structural styles and Dolomites field trip. Memorie Descrittive della Carta Geologica d'Italia, vol. 82, pp. 1-293.

Emanuel R.E., Epstein, H.E., McGlynn, B.L., Welsch, D.L., Muth, D.J., D’Odorico, P. 2010. Spatial and temporal controls on watershed ecohydrology in the northern Rocky Mountains. Water Resources Research 46, W11553. http://doi.org/10.1029/2009WR008890.

Evans C., Davies, T.D. 1998. Causes of concentration/discharge hysteresis and its potential as a tool for analysis of episode geochemistry. Water Resources Research 34, 129-137. http://doi. org/10.1029/97WR01881.

Fang, X., Pomeroy, J.W., Ellis, C.R., MacDonald, M.K., DeBeer, C.M., Brown, T. 2013. Multivariable evaluation of hydrological model predictions for a headwater basin in the Canadian Rocky Mountains. Hydrology and Earth System Sciences 17, 1635-1659. http://doi. org/10.5194/hess-17-1635-2013.

Farrick, K.K., Branfireun, B.A. 2014. Soil water storage, rainfall and runoff relationships in a tropical dry forest catchment. Water Resources Research 50, 9236-9250. http://doi. org/10.1002/2014WR016045.

Fischer, B.M.C., Rinderer, M., Schneider, P., Ewen, T., Seibert, J. 2015. Contributing sources to baseflow in pre-alpine headwaters using spatial snapshot sampling. Hydrological Processes 29, 5321-5336. http://doi.org/10.1002/hyp.10529.

Fovet, O., Ruiz, L., Hrachowitz, M., Faucheux, M., Gascuel-Odoux, C. 2015. Hydrological hysteresis and its value for assessing process consistency in catchment conceptual models. Hydrology and Earth System Sciences 19, 105-123. http://doi.org/10.5194/hess-19-105-2015.

Frisbee, M.D., Phillips, F.M., Weissmann, G.S., Brooks, P.D., Wilson, J.L., Campbell, A.R., Liu F. 2012. Unravelling the mysteries of the large watershed black box: Implications for the 
streamflow response to climate and landscape perturbations. Geophysical Research Letters 39, L01404. http://doi.org/10.1029/2011GL050416.

Fu, C., Cheng, J., Jiang, H., Dong, L. 2013. Threshold behavior in a fissured granitic catchment in southern China: (1) analysis of field monitoring results. Water Resources Research 49, 1-17. http://doi.org/10.1002/wrcr.20191.

Gallart, F., Llorens, P., Latron, J., Regüés, D. 2002. Hydrological processes and their seasonal controls in a small Mediterranean mountain catchment in the Pyrenees. Hydrology and Earth System Sciences 6, 527-537. http://doi.org/10.5194/hess-6-527-2002, 2002.

Gannon, J.P., Bailey, S.W., McGuire, K.J. 2014. Organizing groundwater regimes and response thresholds by soils: Aframework for understanding runoff generation in a headwater catchment. Water Resources Research 50, 8403-8419. http://doi.org/10.1002/2014WR015498.

Gannon, J.P., Bailey, S.W., McGuire, K.J., Shanley, J.B. 2015. Flushing of distal hillslopes as an alternative source of stream dissolved organic carbon in a headwater catchment. Water Resources Research 51 (10), 8114-8128. http://doi.org/10.1002/2015WR016927.

Grabs, T.J., Jencso, K.G., McGlynn, B.L., Seibert, J. 2010. Calculating terrain indices along streams: A new method for separating stream sides. Water Resources Research 46, W12536. http://doi.org/10.1029/2010WR009296.

Green, M.B., Laursen, B.K., Campbell, J.L., McGuire, K.J., Kelsey, E.P. 2015. Stable water isotopes suggest sub-canopy water recycling in a northern forested catchment. Hydrological Processes 29, 5193-5202. http://doi.org/10.1002/hyp.10706.

Haga, H., Matsumoto, Y., Matsutani, J., Fujita, M., Nishida, K., Sakamoto, Y. 2005. Flow paths, rainfall properties, and antecedent soil moisture controlling lags to peak discharge in a granitic unchanneled catchment. Water Resources Research 41, W12410. http://doi. org/10.1029/2005WR004236.

Hewlett, J.D., Hibbert, A.R. 1967. Factors affecting the response of small watersheds to precipitation in humid areas. In: W. Sopper, H.W. Lull (Eds.), Forest Hydrology, Pergamon, Oxford, pp. 275-290.

Holko, L., Kostka, Z. 2006. Hydrological research in a high-mountain catchment of the Jalovecký creek. Journal of Hydrology and Hydromechanics 54 (2), 192-206.

Holko, L., Kostka, Z. 2010. Hydrological processes in mountains - knowledge gained in the Jalovecky Creek catchment, Slovakia. IAHS Publications 336, 84-89.

Holko, L., Gorbachova, L. Kostka, Z. 2011. Snow hydrology in central Europe. Geography Compass 5, 200-218. http://doi.org/10.1111/j.1749-8198.2011.00412.x.

Holko, L., Holzmann, H., de Lima, M.I.P., de Lima, J.L.M.P. 2015. Hydrological research in small catchments - an approach to improve knowledge on hydrological processes and global change impacts. Journal of Hydrology and Hydromechanics 63 (3), 181-182. http://doi. org/10.1515/johh-2015-0032.

Hooper, R.P., Christophersen, N., Peters N.E. 1990. Modelling streamwater chemistry as a mixture of soilwater end members - an application to the Panola Mountain Catchment, Georgia, USA. Journal of Hydrology 116, 321-343. http://doi.org/10.1016/0022-1694(90)90131-G.

Inamdar, S., Dhillon, G., Singh, S., Dutta, S., Levia, D., Scott, D., Mitchell, M., van Stan, J., McHale, P. 2013. Temporal variation in end-member chemistry and its influence on runoff mixing patterns in a forested, Piedmont catchment. Water Resources Research 49, 18281844, http://doi.org/10.1002/wrcr.20158.

James, A.L., Roulet, N.T. 2007. Investigating hydrologic connectivity and its association with threshold change in runoff response in a temperate forested watershed. Hydrological Processes 21,3391-3408. http://doi.org/10.1002/hyp.6554. 
Jasechko, S., Kirchner, J.W., Welker, J.M., McDonnell, J.J. 2016. Substantial proportion of global streamflow less than three months old. Nature Geoscience 8, 126-129. http://doi.org/10.1038/ ngeo2636.

Jasechko, S., Wassenaar, L.I., Mayer, B. 2017. Isotopic evidence for widespread cold-seasonbiased groundwater recharge and young streamflow across central Canada. Hydrological Processes 31, 2196-2209. http://doi.org/10.1002/hyp.11175.

Jencso, K.G., McGlynn, B.L., Gooseff, M.N., Wondzell, S.M., Bencala, K.E., Marshall, L.A. 2009. Hydrologic connectivity between landscapes and streams: Transferring reach- and plot-scale understanding to the catchment scale. Water Resources Research 45, W04428. http://doi. org/10.1029/2008WR007225.

Jencso, K.G., McGlynn, B.L., Gooseff, M.N., Bencala, K.E., Wondzell, S.M. 2010. Hillslope hydrologic connectivity controls riparian groundwater turnover: Implications of catchment structure for riparian buffering and stream water sources. Water Resources Research 46, W10524. http://doi.org/10.1029/2009WR008818.

Juras, R., Pavlásek, J., Vitvar, T., Šanda, M., Holub, J., Jancovec, J., Linda, M. 2016. Isotopic tracing of the outflow during artificial rain-on-snow event. Journal of Hydrology 541, 1145 1154. http://doi.org/j.jhydrol.2016.08.018.

Kaiser, K.E., McGlynn, B.L., Emanuel, R.E. 2013. Ecohydrology of an outbreak: Mountain pine beetle impacts trees in drier landscape positions first. Ecohydrology 6, 444-454. http://doi. org/10.1002/eco.1286.

Karlsen, R.H., Grabs, T., Bishop, K., Buffam, I., Laudon, H., Seibert, J. 2016. Landscape controls on spatiotemporal discharge variability in a boreal catchment. Water Resources Research 52 , 6541-6556. http://doi.org/10.1002/2016WR019186.

Kirchner, J.W. 2016. Aggregation in environmental systems - Part 1: Seasonal tracer cycles quantify young water fractions, but not mean transit times, in spatially heterogeneous catchments. Hydrology and Earth System Sciences 20, 279-297. http://doi.org/10.5194/hess20-279-2016.

Klaus, J., McDonnell, J.J., Jackson, C.R., Du, E., Griffiths, N.A. 2015. Where does streamwater come from in low-relief forested watersheds? A dual-isotope approach. Hydrology and Earth System Sciences 19, 125-135. http://doi.org/10.5194/hess-19-125-2015.

Laudon, H., Löfvenius, O.M. 2016. Adding snow to the picture - providing complementary winter precipitation data to the Krycklan catchment study database. Hydrological Processes, 30 2413-2416. http://doi.org/10.1002/hyp.10753.

Latron, J., Gallart, F. 2008. Runoff generation processes in a small Mediterranean research catchment (Vallcebre, Eastern Pyrenees). Journal of Hydrology 358, 206-220. http://doi. org/10.1016/j.jhydrol.2008.06.014.

Lawler, D.M., Petts, G.E., Foster, I.D.L., Harper, S. 2006. Turbidity dynamics during spring storm events in an urban headwater river system: The Upper Tame, West Midlands, UK. Science of the Total Environment 360, 109-126. http://doi.org/10.1016/j.scitotenv.2005.08.032.

Lehmann, P., Hinz, C., McGrath, G., Tromp-van Meerveld, H.J., McDonnell, J.J. 2007. Rainfall threshold for hillslope outflow: An emergent property of flow pathway connectivity. Hydrology and Earth System Sciences 11, 1047-1063. http://doi.org/10.5194/hess-11-10472007.

Lloyd, C.E.M., Freer, J.E., Johnes, P.J., Collins, A.L. 2016a. Using hysteresis analysis of highresolution water quality monitoring data, including uncertainty, to infer controls on nutrient and sediment transfer in catchments. Science of the Total Environment 543, 388-404. http:// doi.org/10.1016/j.scitotenv.2015.11.028. 
Lloyd, C.E.M., Freer, J.E., Johnes, P.J., Collins, A.L. 2016b. Technical Note: Testing an improved index for analysing storm discharge-concentration hysteresis. Hydrology and Earth System Sciences 20, 625-632. http://doi.org/10.5194/hess-20-625-2016.

McDonnell, J.J. 2003. Where does water go when it rains? Moving beyond the variable source area concept of rainfall-runoff response. Hydrological Processes 17, 1869-1875. http://doi. org/10.1002/hyp.5132.

McDonnell, J.J., Bonell, M., Stewart, M.K., Pearce, A.J. 1990. Deuterium variations in storm rainfall - implications for stream hydro-graph separation. Water Resources Research 26 (3), 455-458. http://doi.org/10.1029/WR026i003p00455.

McGuire, K.J., McDonnell, J.J. 2010. Hydrological connectivity of hillslope and streams: characteristic time scales and nonlinearities. Water Resources Research 46, W10543. http:// doi.org/10.1029/2010WR009341.

Mirus, B.B., Loague, K. 2013. How runoff begins (and ends): Characterizing hydrologic response at the catchment scale. Water Resources Research, 49. http://doi.org/10.1002/wrcr.20218.

Ocampo, C.J., Sivapalan, M., Oldham, C. 2006. Hydrological connectivity of upland-riparian zones in agricultural catchments: implications for runoff generation and nitrate transport. Journal of Hydrology 331, 643-658. http://doi.org/10.1016/j.jhydrol.2006.06.010.

Pacific, V.J., Jencso, K.G., McGlynn, B.L. 2010. Variable flushing mechanisms and landscape structure control stream DOC export during snowmelt in a set of nested catchments. Biogeochemistry 99 (1-3), 193-211. http://doi.org/10.1007/s10533-009-9401-1.

Pacific, V.J., McGlynn, B.L., Riveros-Iregui, D.A., Welsch, D.L., Epstein, H.E. 2011. Landscape structure, groundwater dynamics, and soil water content influence soil respiration across riparian-hillslope transitions in the Tenderfoot Creek Experimental Forest, Montana. Hydrological Processes 25, 811-827. http://doi.org/10.1002/hyp.7870.

Penna, D., Stenni, B., Šanda, M., Wrede, S., Bogaard, T.A., Gobbi, A., Borga, M., Fischer, B.M.C., Bonazza, M., Chárová, Z. 2010a. On the reproducibility and repeatability of laser absorption spectroscopy measurements for $\delta^{2} \mathrm{H}$ and $\delta^{18} \mathrm{O}$ isotopic analysis. Hydrology and Earth System Sciences 14, 1551-1566. http://doi.org/10.5194/hess-14-1551-2010.

Penna, D., Borga, M., Sangati, M., Gobbi A. 2010b. Dynamics of soil moisture, subsurface flow and runoff in a small alpine basin. In: A. Herrmann, S. Schumann (Eds.), Status and Perspectives of Hydrology in Small Basins. IAHS Publications 336, 96-102.

Penna, D., Tromp-van Meerveld, H.J., Gobbi, A., Borga, M., Dalla Fontana, G. 2011. The influence of soil moisture on threshold runoff generation processes in an alpine headwater catchment. Hydrology and Earth System Sciences 15, 689-702. http://doi.org/10.5194/hess-15-689-2011.

Penna, D., Stenni, B., Šanda, M., Wrede, S., Bogaard, T.A., Michelini, M., Fischer, B.M.C., Gobbi, A., Mantese, N., Zuecco, G., Borga, M., Bonazza M., Sobotková M., Čejková B., Wassenaar, L.I. 2012. Technical Note: Evaluation of between-sample memory effects in the analysis of $\delta^{2} \mathrm{H}$ and $\delta^{18} \mathrm{O}$ of water samples measured by laser spectroscopes. Hydrology and Earth System Sciences 16, 3925-3933. http://doi.org/10.5194/hess-16-3925-2012.

Penna, D., Brocca, L., Borga, M., Dalla Fontana, G. 2013. Soil moisture temporal stability at different depths on two alpine hillslopes during wet and dry periods. Journal of Hydrology 477, 55-71. http://doi.org/10.1016/j.jhydrol.2012.10.052.

Penna, D., Mantese, N., Hopp, L., Dalla Fontana, G., Borga, M. 2015. Spatio-temporal variability of piezometric response on two steep alpine hillslopes. Hydrological Processes, 29, 198-211. http://doi.org/10.1002/hyp.10140.

Penna, D., van Meerveld, H.J., Zuecco, G., Dalla Fontana, G., Borga, M. 2016. Hydrological response of an Alpine catchment to rainfall and snowmelt events. Journal of Hydrology 537, 382-397. http://doi.org/10.1016/j.jhydrol.2016.03.040. 
Penna, D., Zuecco, G., Crema, S., Trevisani, S., Cavalli, M., Pianezzola, L., Marchi, L., Borga, M. 2017. Response time and water origin in a steep nested catchment in the Italian Dolomites: Response time and water origin in a nested catchment. Hydrological Processes 31, 768-782. http://doi.org/10.1002/hyp.11050.

Peralta-Tapia, A., Sponseller, R.A., Ågren, A., Tetzlaff, D., Soulsby, C., Laudon, H. 2015a. Scaledependent groundwater contributions influence patterns of winter baseflow stream chemistry in boreal catchments. Journal of Geophysical Research: Biogeosciences 120 (5), 847-858. http://doi.org/10.1002/2014JG002878.

Peralta-Tapia, A., Sponseller, R.A., Tetzlaff, D., Soulsby, C., Laudon, H. 2015b. Connecting precipitation inputs and soil flow pathways to stream water in contrasting boreal catchments. Hydrological Processes 29, 3546-3555. http://doi.org/10.1002/hyp.10300.

Peralta-Tapia, A., Soulsby, C., Tetzlaff, D., Sponseller, R., Bishop, K., Laudon, H. 2016. Hydroclimatic influences on non-stationary transit time distributions in a boreal headwater catchment. Journal of Hydrology 543, 7-16. http://doi.org/10.1016/j.jhydrol.2016.01.079.

Pfister, L., Martínez-Carreras, N., Hissler, C., Klaus, J., Carrer, G.E., Stewart, M.K., McDonnell, J.J. 2017. Bedrock geology controls on catchment storage, mixing, and release: A comparative analysis of 16 nested catchments. Hydrological Processes 31, 1828-1845. http:// doi.org/10.1002/hyp.11134.

Phillips, J.D. 2003. Sources of nonlinearity and complexity in geomorphic systems. Progress in Physical Geography 27 (1), 1-23. http://doi.org/10.1191/ 0309133303pp340ra.

Phillips, J.D. 2006. Evolutionary geomorphology: Thresholds and nonlinearity in landform response to environmental change. Hydrology and Earth System Sciences 10, 731-742. http:// doi.org/10.5194/hess-10-731-2006.

Phillips, R.W., Spence, C., Pomeroy, J.W. 2011. Connectivity and runoff dynamics in heterogeneous basins. Hydrological Processes 25, 3061-3075. http://doi.org/10.1002/hyp.8123.

Pinder, G.F., Jones, J.F. 1969. Determination of ground-water component of peak discharge from chemistry of total runoff. Water Resources Research 5 (2), 438-445. http://doi.org/10.1029/ WR005i002p00438.

Pomeroy, J., Fang, X., Ellis, C. 2012. Sensitivity of snowmelt hydrology in Marmot Creek, Alberta, to forest cover disturbance. Hydrological Processes 26, 1891-1904. http://doi.org/10.1002/ hyp. 9248 .

Prowse, C.W. 1984. Some thoughts on lag and hysteresis. Area 16, 17-23.

Radatz, T.F., Thompson, A.M., Madison, F.W. 2013. Soil moisture and rainfall intensity thresholds for runoff generation in southwestern Wisconsin agricultural watersheds. Hydrological Processes 27, 3521-3534. http://doi.org/10.1002/hyp.9460.

Rinderer, M., van Meerveld, H.J., Seibert, J. 2014. Topographic controls on shallow groundwater levels in a steep, prealpine catchment: When are the TWI assumptions valid? Water Resources Research 50, 6067-6080. http://doi.org/10.1002/2013WR015009.

Riveros-Iregui, D.A., McGlynn, B.L., Marshall, L.A., Welsch, D.L., Emanuel, R.E., Epstein, H.E. 2011. A watershed-scale assessment of a process soil CO2 production and efflux model. Water Resources Research 47, W00J04. http://doi.org/10.1029/2010WR009941.

Šanda, M., Kulasová,A., Císlerová, M. 2009. Hydrological processes in the subsurface investigated by water isotopes and silica. Soil \& Water Research 4, 2009 (Special Issue 2), S83-S92.

Šanda, M., Vitvar, T., Kulasová, A., Jankovec, J., Císlerová, M. 2014. Run-off formation in a humid, temperate headwater catchment using a combined hydrological, hydrochemical and isotopic approach (Jizera Mountains, Czech Republic). Hydrological Processes 28, 3217 3229. http://doi.org/10.1002/hyp.9847. 
Schumann, S., Schmalz, B., Meesenburg, H., Schröder, U. (Eds.) 2010. Status and perspectives of hydrology in small basins. Results of the International Workshop in Goslar-Hahnenklee, 2009 and Inventory of Small Hydrological Research Basins. IHP/HWRP-Berichte 10, Koblenz.

Shanley, J.B., Sebestyen, S.D., McDonnell, J.J., McGlynn, B.L., Dunne, T. 2015. Water's way at Sleepers River watershed - revisiting flow generation in a post-glacial landscape, Vermont USA. Hydrological Processes 29, 3447-3459. http://doi.org/10.1002/hyp.10377.

Sidle, R.C., Tsuboyama, Y., Noguchi, S., Hosoda, I., Fujieda, M., Shimizu, T. 2000. Stormflow generation in steep forested headwaters: A linked hydrogeomorphic paradigm. Hydrological Processes 14, 369-385. http://doi.org/10.1002/(SICI)1099-1085(20000228) 14:3<369::AIDHYP943>3.0. CO;2-P.

Simoni, S., Padoan, S., Nadeau, D.F., Diebold, M., Porporato, A., Barrenetxea, G., Ingelrest, F., Vetterli, M., Parlange, M.B. 2011. Hydrologic response of an alpine watershed: Application of a meteorological wireless sensor network to understand streamflow generation. Water Resources Research 47, W10524. http://doi.org/10.1029/2011WR010730.

Sklash, M.G., Farvolden, R.N. 1979. Role of groundwater in storm runoff. Journal of Hydrology 86243(1-4), 45-65. http://doi.org/10.1016/0022-1694(79)90164-1.

Teutschbein, C., Grabs, T., Karlsen, R.H., Laudon,H., Bishop, K. 2016. Hydrological response to changing climate conditions: Spatial streamflow variability in the boreal region. Water Resources Research 51, 9425-9446. http://doi.org/10.1002/2015WR017337.

Tetzlaff, D., Buttle, J., Carey, S.K., Van Huijgevoort, M.H.J., Laudon, H., McNamara, J.P., Mitchell, C.P.J., Spence, C., Gabor, R.S., Soulsby, C. 2015.A preliminary assessment of water partitioning and ecohydrological coupling in northern headwaters using stable isotopes and conceptual runoff models. Hydrological Processes 29, 5153-5173. http://doi.org/10.1002/ hyp. 10515 .

Tromp-van Meerveld, H.J., McDonnell, J.J. 2006a. Threshold relations in subsurface stormflow: 1: A 147-storm analysis of the Panola hillslope. Water Resources Research 42, W02410. http:// doi.org/10.1029/2004WR003778.

Tromp-van Meerveld, H.J., McDonnell, J.J. 2006b. Threshold relations in subsurface stormflow: 2: The fill and spill hypothesis, Water Resources Research 42, W02411. http://doi. org/10.1029/2004WR003800.

Vidon, P.G. 2015. Field hydrologists needed: a call for young hydrologists to (re)-focus on field studies. Hydrological Processes 29, 5478-5480. http://doi.org/10.1002/hyp.10614.

Vitvar, T., Aggarwal, P.K., McDonnell, J.J. 2005. A review of isotope applications in catchment hydrology. In: P.K. Aggarwal, J.R. Gat, K.F. Froehlich (Eds.), Isotopes in the Water Cycle: Past, Present and Future of a Developing Science, Springer, pp. 151-169.

Vogel, T., Sanda, M., Dusek, J., Dohnal, M., Votrubova, J. 2010. Using oxygen-18 to study the role of preferential flow in the formation of hillslope runoff. Vadose Zone Journal 9, 252-259. http://doi.org/10.2136/vzj2009.0066.

von Freyberg, J., Radny, D., Gall, H.E., Schirmer, M. 2014. Implications of hydrologic connectivity between hillslopes and riparian zones on streamflow composition. Journal of Contaminant Hydrology 169, 62-74. http://doi.org/10.1016/j.jconhyd.2014.07.005.

Votrubova, J., Dohnal, M., Vogel, T., Sanda, M., Tesar, M. 2017. Episodic runoff generation at Central European headwater catchments studied using water isotope concentration signals. Journal of Hydrology and Hydromechanics 65 (2), 114-122. http://doi.org/10.1515/johh-2017-0002.

Zabaleta, A., Antigüedad, I. 2013. Streamflow response of a small forested catchment on different timescales. Hydrology and Earth System Sciences 17, 211-223. http://doi.org/10.5194/hess17-211-2013.

Zehe, E., Graeff, T., Morgner, M., Bauer, A., Bronstert, A. 2010. Plot and field scale soil moisture dynamics and subsurface wetness control on runoff generation in a headwater in the Ore 
Mountains. Hydrology and Earth System Sciences 14, 873-889. http://doi.org/10.5194/hess14-873-2010.

Zuecco, G., Penna, D., Borga M., van Meerveld, H.J. 2016. A versatile index to characterize hysteresis between hydrological variables at the runoff event timescale. Hydrological Processes 30, 1449-1466. http://doi.org/10.1002/hyp.10681.

Zuecco, G., Rinderer, M., Penna, D., Borga M., Van Meerveld, H.J. in review. Quantification of subsurface hydrologic connectivity in four headwater catchments using graph theory. Science of Total Environment. 